medRxiv preprint doi: https://doi.org/10.1101/2020.05.14.20102475; this version posted May 20, 2020. The copyright holder for this preprint (which was not certified by peer review) is the author/funder, who has granted medRxiv a license to display the preprint in perpetuity. It is made available under a CC-BY-NC-ND 4.0 International license .

\title{
COVID-19; Systematic and literature review of transmission, case definitions, clinical management and clinical trials.
}

\author{
Laura McArthur ${ }^{1}$, DhanaSekaran Sakthivel ${ }^{2}$, Ricardo Ataide ${ }^{3,4}$, Felicia Chan ${ }^{5}$, Jack S. \\ Richards $^{2,3,6}$, Charles A. Narh ${ }^{2,3,6^{*}}$ \\ ${ }^{1}$ School of Medicine, Monash University, Clayton, VIC 3800, Australia. \\ ${ }^{2} Z$ iP Diagnostics Pty Ltd, Collingwood, VIC 3066, Australia. \\ ${ }^{3}$ Department of Medicine, University of Melbourne, VIC 3010, Melbourne, Australia. \\ ${ }^{4}$ Walter and Eliza Hall Institute, Melbourne, Australia \\ ${ }^{5}$ Central Clinical School, Monash University, Clayton, VIC 3800, Australia. \\ ${ }^{6}$ Burnet Institute for Medical Research, VIC 3004, Melbourne, Australia. \\ *Correspondence: Charles A. Narh \\ charles.narh@burnet.edu.au
}

Keywords: Coronavirus, COVID-19, SARS-CoV-2, transmission, management, treatment, clinical, symptoms.

\section{Abstract}

Background: SARS-CoV-2, the viral agent responsible for coronavirus disease 2019 (COVID-19) was identified in Wuhan, China at the end of December 2019. It rapidly spread to the rest of the world, and was declared a Public Health Emergency of International Concern on the 30th of January 2020. Our understanding of the virus, it's clinical manifestations and treatment options continues to evolve at an unparalleled pace.

Objective: This review sought to summarise the key literature regarding transmission, case definitions, clinical management and trials, and performed a systematic review of reported clinical data on COVID-19.

Synthesis methods: Two reviewers selected all the literature independently, and extracted information according to pre-defined topics.

Results: COVID-19 is pandemic with $\sim 4$ million cases and 270,000 deaths in 210 countries as of 8 May 2020. Our review of reports showed that SARS-CoV-2 was mainly transmitted via inhalation of respiratory droplets containing the virus and had an incubation period of four to six days. The commonly reported symptoms were fever (80\%) and cough $(60 \%)$ across the spectrum of clinical disease - mild, moderate, severe and critical. Categorization of these cases for home care or hospital management need to be well defined considering the age of the patient and the presence of underlying co-morbidities. The case definitions we reviewed varied among affected countries, which could have contributed to the differences observed in the mean case fatality rates among continents - Oceania (1\%), Asia (3\%), Africa (4\%), South America (5\%), North America $(6 \%)$ and Europe (10\%). Asymptomatic cases, which constituted an estimated $80 \%$ of COVID-19 cases are a huge threat to control efforts.

Conclusion: The presence of fever and cough may be sufficient to warrant a COVID-19 testing but using these symptoms in isolation will miss a proportion of cases. A clear definition of a COVID-19 case is important for managing, treating and tracking clinical illness. While several treatments are in development or in clinical trials for COVID-19, home care of mild/moderate 
medRxiv preprint doi: https://doi.org/10.1101/2020.05.14.20102475; this version posted May 20, 2020. The copyright holder for this preprint

(which was not certified by peer review) is the author/funder, who has granted medRxiv a license to display the preprint in perpetuity.

It is made available under a CC-BY-NC-ND 4.0 International license .

cases and hospital care for severe and critical cases remain the recommended management for the disease. Quarantine measures and social distancing can help control the spread of SARS-CoV-2.

\section{Introduction}

In December 2019 a number of Chinese Health Centres reported a cluster of patients with pneumonia of unknown aetiology in Wuhan, Hubei Province $(1,2)$. Their clinical presentations were similar to the Severe Acute Respiratory Syndrome (SARS) outbreak that occurred in 2003 (3-5). COVID-19 is the third coronavirus disease to cause public health outbreaks and has spread more rapidly and widely than SARS and Middle East Respiratory Syndrome (MERS). As of $8^{\text {th }}$ May 2020, there were $\sim 4$ million confirmed cases and $\sim 270,000$ deaths in 210 countries and territories. This review provides a discussion of the disease transmission, clinical presentations, variability of case definitions and review of the clinical management and clinical trials of drugs for COVID-19.

\section{Methods}

\section{Literature search}

This study was conducted following the PRISMA recommended guidelines (see Supplementary data for PRISMA check list version 2009) where relevant. Literature search for articles relevant for the topics discussed in this review was performed using OVID Medline, PubMed and Google Scholar. The search terms included "SARS-CoV-2 and Wuhan", "Transmission and reproductive number and SARS-CoV-2", "SARS-CoV-2 and COVID-19", "COVID-19 and case definitions", "COVID-19 and symptoms and clinical", "COVID-19 and asymptomatic", "COVID-19 and risk factors", "COVID-19 and treatments and hospital" and "COVID-19 and adults or children". Furthermore, references within the articles that were returned by the search engines were also retrieved and reviewed if they contained relevant information for this current review. Medical review sites including BMJ Best Practice and UpToDate were reviewed periodically to provide background and to get updates on COVID-19. For case definitions, the WHO criteria and those published by individual countries in the six continents were obtained. For case management, the NIH Clinical Trials database (https://clinicaltrials.gov/) was reviewed. The list of drugs and treatments in development and clinical trials for COVID-19 were obtained through periodic searches of News articles, Press releases and reports in the medical journals. Relevant Preprints on biorxiv and Medrxiv were included only affect they were critically evaluated by two independent reviewers.

\section{Data collection and analysis}

To determine the commonly reported symptoms for COVID-19, data was extracted from 15 studies that involved COVID-19 patients including children and adults (6-20) (Figure S1). For each study, the proportion of patients who reported or were observed to have a particular symptom was recorded in an excel table. For each symptom, the average proportion of the number of patients with that symptom was estimated and plotted with the upper standard error using Microsoft Excel. For each country, data on the total number of cases and deaths reported since the outbreak began till $8^{\text {th }}$ May 2020 were retrieved from Worldometer (21). The case fatality rate was estimated as a percentage of the quotient of the total number of deaths reported and total number of cases reported for each country. The total number of deaths and case fatality rates were plotted for countries with 
$\geq 15$ deaths reported. All mapping analyses were performed using QGIS 3.12.1-București (http://qgis.osgeo.org). Shapefiles for country borders were downloaded from Natural Earth (Free vector and raster map data at naturalearthdata.com). The data extracted from Worldometer (21) was imported to Stata/SE 16.1 (StataCorp, TX, USA) and the country names were spelt to match those of the country shapefile. The resulting database was exported as a csv file and imported to QGIS where a join was performed using the MMQIS Plugin developed by Michael Minn v.2020.1.16. http://michaelminn.com/linux/mmqgis/).

96

97

98

99

100

101

102

103

104

105

106

107

108

109

110

111

112

113

114

115

116

117

118

119

120

121

122

123

124

125

126

127

128

129

130

131

132

133

134

\section{Human-to-human transmission routes of SARS-CoV-2}

SARS-CoV-2 is transmitted between humans via respiratory droplets which are produced when an infected individual talks, sneezes or coughs (Figure 1). Droplet transmission can occur within 1-4 meters $(15,22,23)$. SARS-CoV-2 has been shown to survive in aerosolised form for more than 3 hours under experimental conditions, but this mechanical generation of aerosols is unlikely to mimic the true clinic scenario (24). Certain clinical procedures involving the upper airway, such as obtaining a nose or throat swab, endotracheal intubation, manual ventilation or nebulisation are capable of generating particles $<5 \mu \mathrm{m}$, allowing for airborne transmission in healthcare settings (23). In particular, intensive care units (ICU) have been associated with a higher risk of infection (22).

Fomite transmission, transmission from contact with contaminated surfaces, is possible with high rates of contamination of floors and the soles of healthcare staff as well as computer mice, doorknobs and trash cans (22). The virus is viable for up to 72 hours on plastic and stainless steel, 24 hours on cardboard and 4 hours on copper. These survival times appear to be longer than that of SARS-CoV under similar conditions and may contribute to the wider spread of SARS-CoV-2 than SARS-CoV (24).

Infection from direct contact with body fluids from infected individuals is likely to be another possible route of transmission. SARS-CoV-2 has been detected in saliva, blood, urine, tears, faeces and cerebrospinal fluid samples (25-29). While documented evidence of transmission through these alternate sources remains unsubstantiated, precautions when handling samples collected from suspected or confirmed cases is advisable.

\section{Rate of transmission of SARS-CoV-2}

The basic reproductive number $\left(\mathrm{R}_{0}\right)$ of SARS-CoV-2 varies between populations and depends on demographic and environmental factors as well as on the control interventions in place (30). At the onset of the outbreak in Wuhan, before travel restrictions were introduced, the estimated $\mathrm{R}_{0}$ was 2.35 (95\% CI 1.15-4.77) but was reportedly reduced to 1.05 (95\% CI 0.41-2.39) a week later (31). Similarly, aboard the Diamond Princess cruise ship - which carried $\sim 3600$ people, had 712 cases of COVID-19 and 13 deaths reported - the $\mathrm{R}_{0}$ was reported as 14.8 before quarantine/isolation measures were introduced and was reduced to 1.78 after those measures were introduced (32). In closed settings, such as nursing facilities, SARS-CoV-2 may spread rapidly with one study finding a $64 \%$ positivity rate among residents 23 days after the first positive test (33). Of these patients, $56 \%$ tested positive while still asymptomatic, and it has been hypothesised that asymptomatic individuals contribute significantly to transmission (33). 
medRxiv preprint doi: https://doi.org/10.1101/2020.05.14.20102475; this version posted May 20, 2020. The copyright holder for this preprint (which was not certified by peer review) is the author/funder, who has granted medRxiv a license to display the preprint in perpetuity.

\section{Clinical presentation of SARS-CoV-2 infections}

The reported incubation period for SARS-CoV-2 has been variable between different studies, but has generally ranged between 2-11 days, with an average of 4-6 days (34). In one study, the incubation period was estimated at 4.9 days (95\% CI 4.4-5.5) and was not significantly different from that of SARS-CoV (4.7, 95\% CI 4.3-5.1) and MERS-CoV (5.8, 95\% CI 5.0-6.5) (35).

Symptomatic patients with COVID-19 develop a clinical syndrome similar to the influenza (Figure 2). Our analysis of 15 studies involving COVID-19 patients showed that the majority of patients with clinical disease had fever (80\%) and cough (60\%) and myalgia/fatigue (40\%; Figure 2). Other reported symptoms were less common and included dyspnoea, sore throat, diarrhoea, vomiting, pharyngeal congestion, headache, sputum production, anorexia and chest pain (1, 36-39). The majority of these symptoms appeared within 11 days post-infection but may vary depending on age and co-morbidities $(6,30,40,41)$. See section 6 for a review of factors associated with disease severity. See Figure S1 for a detailed analysis of the reported symptoms for each of the 15 studies were the clinical data in Figure 2 was obtained.

Where illness warrants hospitalisation, studies suggest that this usually occurs within five days of symptom onset (30), with a mean time to hospitalisation of seven days (7). The average time of hospital admission ranged from 12.8 - 17 days and was dependent on disease severity $(6,42)$. WHO recommends 2-6 weeks of hospitalisation to allow time for proper treatment and adequate recovery (43). The disease can progress from mild to critical with severe respiratory complications and multiple organ dysfunction, which can be fatal $(1,37,44)$. In COVID-related deaths, the median time from symptom onset to death is about 13 days (45).

\subsection{Asymptomatic cases}

160 Asymptomatic SARS-CoV-2 infections, where patients test positive for the virus yet remain 161 clinically well, constitute a large proportion of COVID-19 cases. As such, a population screening strategy based on clinical symptoms alone will miss these cases. Estimates suggest that up to $80 \%$ of people who test positive for SARS-CoV-2 are asymptomatic (46). In a proportion of individuals who are initially asymptomatic, a clinical illness will subsequently develop, classifying this group as pre-symptomatic. A study of asymptomatic patients found that $67.3 \%$ had, as determined by computed tomography (CT), lung abnormalities at admission and 70.9\% later developed a mild illness. In the $32.7 \%$ who did not have initial CT changes, only $11 \%$ later developed clinical illness (47). Pre-symptomatic cases have also comprised the majority of positive results when testing is performed in nursing facilities, with these cases likely contributing to transmission (33).

The distribution of asymptomatic cases varies with age, with the majority of infected children more likely to be asymptomatic compared to adults $(48,49)$. In an analysis of cruise ship infections and Japanese evacuees, mostly adults from Wuhan, asymptomatic cases were estimated to account for $17.9 \%-33.3 \%$ of the total SARS-CoV-2 infections (50). In recent reports from naval officials regarding an outbreak aboard the Theodore Roosevelt, approximately $60 \%$ of positive patients were asymptomatic at the time of testing (51). Given that the majority of these individuals were relatively fit, young and healthy individuals, it suggests that the disease may be more likely to be asymptomatic in this cohort, while still contributing to transmission. 
medRxiv preprint doi: https://doi.org/10.1101/2020.05.14.20102475; this version posted May 20, 2020. The copyright holder for this preprint (which was not certified by peer review) is the author/funder, who has granted medRxiv a license to display the preprint in perpetuity. It is made available under a CC-BY-NC-ND 4.0 International license .

While the degree of infectivity of these asymptomatic patients compared to those with clinical illness remains uncertain, there are documented cases of asymptomatic individuals transmitting the virus during the incubation period, and continuing to shed virus while convalescing (52). Numerous cases of pre-symptomatic transmission have been reported including data that suggested that $12.6 \%$ of cases in China were transmitted asymptomatically (53). These findings raised questions as to whether the majority of the patients who were classified as 'pre-symptomatic' may have had mild symptoms that went unreported $(52,54,55)$. In Singapore, the CDC reports on seven clusters of patients where $6.4 \%$ of cases occurred through pre-symptomatic transmission, between 1-3 days.

\subsection{Mild illness}

Mild COVID-19 illness is defined by uncomplicated symptoms which can be safely managed in the outpatient setting. While the World Health Organisation separates this category into those with and without a mild pneumonia, this distinction does not influence management and is difficult to make in patients managed outside of hospital. For the purposes of this review, all cases suitable for management in an outpatient setting will be considered together.

Mild COVID-19 is perhaps less well understood than more severe disease phenotypes as it is believed that the majority of such cases do not present for testing. Based on current data, approximately $81 \%$ of confirmed SARS-CoV-2 infections are regarded as mild (26); however, it is likely that the number of mild cases has been significantly underestimated. During the early period of the disease outbreak in China, it was estimated that $86 \%$ of infections went undocumented due to the fact that those infected developed non-severe symptoms and therefore did not present for testing (56). The study further estimated that undocumented infections were the sources of infection of $79 \%$ of all documented infections (57).

Symptoms of mild COVID-19 are classically of an upper respiratory tract infection, with atypical presentations being more common in elderly and immunosuppressed individuals (58). It appears that fever is less characteristic of mild cases. In a Dutch study of patients identified through screening, $53.5 \%$ had fever compared to $77-98.6 \%$ of hospitalised patients. Headache and pharyngeal congestion were comparatively prominent with malaise, cough and myalgia being less typical than in severe cases $(7,11,12)$. Although fatalities have been reported among children, they seem more likely to experience a mild illness and the case fatality rate appears significantly lower compared to adults (59). As children can still contribute to transmission, considerations for social distancing remain relevant despite the generally comparative mild illness phenotype in this cohort (41).

\subsection{Severe and critical illness}

Severe COVID-19 is defined by symptoms of significant respiratory distress which in adults are tachypnoea $\geq 30$ breaths per minute; oxygen saturation $\leq 93 \% ; \mathrm{PaO}_{2} / \mathrm{FiO}_{2}$ ratio $<300 \mathrm{mmHg}$; lung infiltrates $>50 \%$ within 24-48 hours; or clinical assessment of severe distress $(58,60)$. This definition encompasses Acute Respiratory Distress Syndrome (ARDS), defined by acute onset, 
medRxiv preprint doi: https://doi.org/10.1101/2020.05.14.20102475; this version posted May 20, 2020. The copyright holder for this preprint (which was not certified by peer review) is the author/funder, who has granted medRxiv a license to display the preprint in perpetuity. It is made available under a CC-BY-NC-ND 4.0 International license .

$\mathrm{PaO}_{2} / \mathrm{FiO}_{2}$ ratio and bilateral infiltrates on CXR (61). Through the course of the illness, most patients will develop a fever, $77-98.6 \%$, and cough, $48.2-76 \%(6,8,26,47)$.

Other common symptoms include myalgia or fatigue, which appear early in the illness and seen in around $18-32.1 \%$ of cases (8), sore throat (19) and dyspnoea (26). Fatigue may ultimately occur in up to $69.6 \%$ of patients through the course of the illness but it is non-specific (47). Anosmia has been reported as a commonly observed symptom and in a recent Italian study $33.9 \%$ of patients reported a disturbance of smell or taste, with most experiencing this prior to their admission to hospital. Less common are gastrointestinal symptoms such as diarrhoea and vomiting, as well as chest pain and pharyngeal congestion. However, it is worth noting that while some symptoms are common - with fever in particular being regarded as a defining symptom of the illness - they are by no means necessary and will not always be present throughout the course of the disease.

Severe COVID-19 occurred in 14\% of documented SARS-CoV-2 infections in China during the initial epidemic period (62). Further studies have determined a need for non-invasive ventilation consistent with severe COVID-19 in 10.8\% (7) to 13.1\% (63) of admitted patients. In addition, current literature records Acute Respiratory Distress Syndrome (ARDS) in 3.4\% (6), 17\% (56), $29 \%$ (26) and $41.8 \%$ (64) of hospitalised COVID-19 patients. Where ARDS develops, Wang et al. observed a mean time from first symptoms to ARDS to be 8 days (7).

The majority of patients, 70.3-83.2\%, with severe cases develop lymphocytopenia (6-8) and CT changes have been identified in $56 \%$ of patients on admission to hospital $(6,65)$. CT changes are of particular note as these may be identified even in asymptomatic individuals, and if present increase the likelihood of a clinical illness developing (47). A moderate disease phenotype may exist in which patients do not meet criteria for severe or critical disease but nevertheless require in-hospital management. This is commonly due to comorbidities, inability to tolerate oral intake, or respiratory distress not yet meeting thresholds for severe disease.

Severe COVID-19 appears to be more common in men, with $54.3-68 \%$ of hospitalised patients in studies being male $(47,56)$ and asymptomatic or mild illnesses having an apparent female preponderance (47). Severe disease has likewise been associated with comorbidities albeit severe illness and death can occur in previously young, healthy individuals including infants $(63,66)$.

Critical cases of COVID-19 are defined by respiratory failure requiring mechanical ventilation; septic shock; or organ dysfunction necessitating intensive care (60). Critical COVID-19 cases were recorded in 5-6\% of SARS-CoV-2 infections during the epidemic phase in China $(60,63)$. In other studies of hospitalised patients, the proportion of COVID-19 cases requiring intensive care unit (ICU) admission ranged from $5 \%$ to $32 \%(6,7,26,67)$. A need for invasive mechanical ventilation has been reported in $2.3-12.3 \%$ of hospitalised patients $(6,7)$ and ultimate requirement for extracorporeal membranous oxygenation (ECMO) in $0.5-3 \%$ of patients $(6,56)$. Critical COVID19 has a case fatality rate of $49.0 \%$ recorded among those with critical disease in China (63).

\subsection{Recovery from COVID-19}

Once patients have recovered, there is some suggestion they may still be able to transmit the virus, with case reports of positive RT-PCR throat swabs 5-13 days after symptom resolution, and potentially present in patients who have previously been swab-negative for SARS-CoV-2 (68). 
medRxiv preprint doi: https://doi.org/10.1101/2020.05.14.20102475; this version posted May 20, 2020. The copyright holder for this preprint (which was not certified by peer review) is the author/funder, who has granted medRxiv a license to display the preprint in perpetuity. It is made available under a CC-BY-NC-ND 4.0 International license .

Viral shedding has been observed for up to 37 days in survivors with a median duration of 20 days (69). SARS-CoV-2 has also been detected in faecal specimens 18-30 days after illness onset in children (19), suggesting that prolonged shedding may still be possible during and after recovery.

To date, studies of vertical transmission of SARS-CoV-2 remain limited but as of yet there are no definitive documented cases (70-72). While SARS-CoV-2 specific IgM has been detected in infant sera of COVID-19 positive mothers, it is as yet uncertain whether this represents passive immunization, such as through an altered placenta or disease transmission with infant immune response (73).

\section{COVID-19 case definitions}

Defining the scope of the COVID-19 pandemic has been affected by the need to refine case definitions as the pandemic progressed and as clinical presentations become more clearly defined. These case definitions have been used to determine whom to test and to guide case investigations of possible contacts. By influencing testing algorithms, they have greatly impacted the confirmed test outcomes. As an example, case definitions in China were changed on the $12^{\text {th }}$ February 2020, to include clinically-diagnosed mild cases, resulting in an increase of $>15,000$ in a single day (74). Thus, developing consistent case definitions, whenever possible, is necessary to track metrics of the disease and its spread.

COVID-19 case definitions have been developed and modified in different jurisdictions according to local circumstances and authorities (Table 1). In Canada, the definition of a probable case has been widened to require only one symptom of illness in addition to an epidemiological risk factor; and the definition of such a risk factor has also been expanded to encompass other sources of exposure, such as laboratory materials. In Australia, where case definitions are used to determine testing priorities, additional efforts have been devoted to defining high-risk settings such as residential facilities and the nature of a close contact as it relates to in-person interactions and proximity (Table 1). These definitions are highly significant as they determine who receives testing and which patients need to be regarded as at-risk for transmitting the virus. These precautions require resources - including equipment and personnel - such that case definitions must balance capturing possible COVID-19 infections against burdening the healthcare system with individuals with a low probability of infection.

\section{Burden and case fatality of COVID-19}

As of $8^{\text {th }}$ May 2020, 4 million confirmed cases and 270,000 deaths due to COVID-19 were reported from 210 countries and territories (Figure 3A) (21). In Asia, where the epidemic started, $\sim 620,000$ cases and $\sim 21,200$ deaths were reported with estimated case mean case fatality of $3 \%$. Although the hardest hit countries in this region were Turkey $(\sim 134,000$ cases: $\sim 3,600$ deaths; $3 \%$ fatality rate), Iran $(\sim 103,000 ; \sim 6,500 ; 6 \%)$ and China $(\sim 82,900 ; \sim 4,600 ; 6 \%)$, Indonesia and the Philippines had the highest case fatality, $\sim 7 \%$ (Figure 3B). It is worth noting that the case definitions were not the same which may affect testing and management of cases. As the epidemic spread farther outside Asia, Europe became the hotspot with $\sim 1.6$ million cases and $\sim 150,000$ deaths with a mean case fatality of $10 \%$ (Figure 3B). The five hardest hit countries include Spain $(\sim 256,900 ; \sim 26,100 ; 10 \%)$, Italy $(\sim 215,900 ; \sim 30,000 ; 14 \%)$, UK $(\sim 206,700 ; \sim 30,600 ; 15 \%)$, Russia $(\sim 177,200 ; 1,600 ; 1 \%)$ and France $(\sim 174,800 ; 26,000 ; 15 \%)$. In North America 
medRxiv preprint doi: https://doi.org/10.1101/2020.05.14.20102475; this version posted May 20, 2020. The copyright holder for this preprint (which was not certified by peer review) is the author/funder, who has granted medRxiv a license to display the preprint in perpetuity. It is made available under a CC-BY-NC-ND 4.0 International license .

$(\sim 1,412,000 ; \sim 85,200 ; 6 \%)$, the United States $(\sim 1,300,000 ; \sim 76,900 ; 6 \%)$ was the hotspot, contributing $\sim 92 \%$ of the total cases from the region (Figure 3A). In South America ( 267,900; $13,600 ; 5 \%)$, Brazil $(\sim 135,800 ; \sim 9,200 ; 7 \%)$, Peru $(\sim 58,500 ; \sim 1,600 ; 3 \%)$ and Ecuador $(\sim 30,300$; $\sim 1,600 ; 5 \%$ ) were the hardest hit (Figure $3 \mathrm{~A})$. In Africa, where $\sim 55,400$ cases were confirmed and $\sim 2,100$ deaths occurred with a mean case fatality of $4 \%$, South Africa $(\sim 8,200 ; 160 ; 2 \%)$, Egypt $(\sim 8,000 ; 500 ; 6 \%)$, Morocco $(5,500 ; 180 ; 3 \%)$ and Algeria $(5,200 ; 500 ; 9 \%)$ were the hardest hit (Figure 3B). Oceania had the lowest number of cases reported so far with $\sim 8,500$ cases and 120 deaths with a mean case fatality of $1 \%$, with the hardest hit country being Australia $(7,000 ; 100$; $1 \%$, Figure 3B). As the pandemic continues, these figures and trends in cases and deaths may change, and thus, it is important for countries to keep track to inform public health control efforts.

In different healthcare settings, the case fatality may vary. Studies of hospitalised patients have reported varying fatality rates ranging from 1.4 to $14 \%(6,41,74)$. However, several of such studies are likely underestimating true fatality rates in these patient groups given that the percentage of patients recovered to discharge by the conclusion of the study often remains low $31 \%$ in the analysis by Chen et al, where case fatality rate was found to be $11 \%(10)$ and $34.1 \%$ in the study by Wang et al, where case fatality rate was $4.3 \%$ (7). In studies that have used the formula of fatal cases/(fatal + recovered) to calculate fatality rates, these have been found to be higher, estimated at $14 \%$ among hospitalised patients (74).

However, when considering all cases of SARS-CoV infection, including those that are not hospitalised, it is likely that the vast majority of mild cases are undocumented and therefore not included in calculations of case fatality rate - which would render it significantly lower than previously believed (57). With these factors complicating estimations of case fatality rate, it is difficult to determine a precise risk, but recent estimates taking these factors into account put the case fatality rate at $0.51 \%$ (75). This is supported by data from cruise ship cohorts. Of cases from the Diamond Princess, a population in which many of the case-finding difficulties were eliminated, studies recorded the case fatality rate at $0.99 \%(76)$.

Despite this uncertainty regarding the precise case fatality rates, it does appear clear that there are several significant risk factors for fatal illness. In early analysis of Chinese data, the risk of death was higher with increasing age, climbing to $8 \%$ among $70-79$ year-olds and $14.8 \%$ among those $\geq 80$ years (62). This was supported by data from Italy (77) where the higher fatality rate was associated with an older population (with $23 \%$ of Italy being $\geq 65$ years) and age-specific death rates rose to $20.2 \%$ among those $\geq 80$ years and $22.7 \%$ among $\geq 90$ years. Likewise, in some studies of hospitalised patients age was associated with disease severity where the risk of severe disease increased with age $(6,47,60,78)$.

\section{Factors associated with infection and morbidity}

COVID-19 mortality risk has also been consistently associated with comorbidities $(6,8)$. In Wu's analysis, it rose from $2.3 \%$ in the general population to $10.5 \%$ among those with cardiovascular diseases, $7.3 \%$ among patients with diabetes mellitus, $6.3 \%$ among those with chronic respiratory diseases, $6 \%$ among patients with hypertension and 5.6\% in cancer patients (63). A subset of fatal cases from Italy have been reported in which $99.2 \%$ had comorbidities of some description, with 48.5\% having at least three underlying diseases (77). In addition, Yang et al. identified chronic illness in $40 \%$ of patients who fell critically ill (13). Other predictors of severe illness and death 
medRxiv preprint doi: https://doi.org/10.1101/2020.05.14.20102475; this version posted May 20, 2020. The copyright holder for this preprint (which was not certified by peer review) is the author/funder, who has granted medRxiv a license to display the preprint in perpetuity. It is made available under a CC-BY-NC-ND 4.0 International license .

may include presentation with dyspnoea (present in 59.5-63.9\% of ARDS cases, versus 19.6$25.6 \%$ of less severe illness) and anorexia $(66.7 \%$ vs. $30.4 \%)(7,64)$. Severe illness has also been associated with smoking (6) and the presence of neutrophilia, higher lactate and d-dimer (64).

Interestingly, host genetic factors including polymorphisms in the human receptor for SARS-CoV2 , the angiotensin-converting enzyme 2 (ACE2), may play a role in infection and severity of COVID-19 (79-81). Compared to European populations, East Asian populations were found to have a higher allele frequency of the ACE2 variant, associated with higher expression of ACE2 receptors (82). This suggests that East Asian and China population might have an increased susceptibility to SARS-CoV-2 infection as compared to European individuals. In contrast, Cai (83) found no difference in the expression level of ACE2 between Asians and Caucasians. Among genders, a study by Zhou et al. (84) found that Chinese males expressed higher levels of ACE2 receptors. These findings are preliminary and inconclusive but they do warrant further investigations.

\section{Management of COVID-19 cases}

For the majority of patients, COVID-19 presents as a mild illness that can be managed at home with rest and simple analgesics/antipyretics for symptom relief (Figure 1). Paracetamol has been suggested as the drug of choice for symptom relief while anecdotal evidence of NSAID-associated harm in COVID-19 infected patients is being investigated (85). Glucocorticoids, previously used in SARS, have been found to be harmful in influenza and MERS-CoV; the CDC and WHO currently recommend against their use for COVID-19 (58).

Currently, most healthcare facilities are attempting to manage milder cases of COVID-19 on an outpatient basis, with patients self-isolating in their own homes. However, it has been questioned whether early intervention with oxygen therapy may be beneficial, with doctors reporting cases of COVID-19 patients with extremely low oxygen saturations, despite relatively mild symptoms (86). These patients may be at increased risk of rapid deterioration and may benefit from early oxygen therapy (86).

Once patients are admitted to hospital, treatments fall into three key categories: supportive care; treatment of coinfection and comorbidity; and disease-modifying treatments, which currently remain experimental.

For patients with severe or critical SARS-CoV-2, supportive care is the current mainstay of treatment (Figure 1). This includes attention to fluids and electrolytes, monitoring for complications, facilitating symptomatic management and providing respiratory support. Respiratory support can be provided in a stepwise fashion as required, moving from oxygen therapy through to non-invasive ventilation then intubation and mechanical ventilation. In ARDS, there is some evidence that prone positioning of patients may improve oxygenation and it is currently being recommended for critical care of COVID-19 patients (59). Extracorporeal membranous oxygenation may be used if available for refractory hypoxia. It is important to note that while respiratory support measures are integral to COVID-19 management, they also create high-risk environments in which airborne transmission of the virus may be possible (23). These measures include intubation, nebulised treatments, moving patients to prone position and positive- 
medRxiv preprint doi: https://doi.org/10.1101/2020.05.14.20102475; this version posted May 20, 2020. The copyright holder for this preprint (which was not certified by peer review) is the author/funder, who has granted medRxiv a license to display the preprint in perpetuity.

It is made available under a CC-BY-NC-ND 4.0 International license .

pressure NIV. During these activities, health care personnel require personal protective equipment including N95 mask and eye protection.

Where COVID-19 is causing severe illness or sepsis, the World Health Organisation recommends empirical antimicrobial treatment, with other sources suggesting this be considered in any severe infection (59). In addition, consideration may be given to a neuraminidase inhibitor in the event of co-infection with influenza. Coinfection of COVID-19 patients with other pathogens may be common, occurring in $22 \%$ of cases in some reports (87). However, this depends on region and season. Coinfection with other respiratory pathogens may increase COVID-19 severity. As such, severe disease warrants testing and treatment.

\section{Drugs in development and in clinical trials for COVID-19}

There are a range of drugs and treatments currently under investigation due to their potential to modify some aspect of the COVID-19 disease course (Table 3).

\section{Remdesivir (GS-5734)}

An adenosine nucleoside analogue produced by Gilead Sciences, remdesivir has previously been under investigation for its use against RNA viruses including Ebola virus (88). Due to pre-existing evidence of efficacy against SARS-CoV and MERS-CoV in vitro and in animal models (89-92), it has been provided on compassionate grounds for some patients with COVID-19 (88) and has recently being approved by the US FDA for emergency use for the treatment of severe cases (93). Multiple trials have been launched into its effectiveness. There is currently limited evidence of its efficacy, with in vitro studies demonstrating inhibition of COVID-19 (94) and a US case report of a patient who improved following IV remedesivir administration (95). A non-randomised study of patients with severe disease who were treated with the drug, based on compassionate grounds, suggested that $68 \%$ experienced improvement in requirements for respiratory support (88). A recent report by US officials claimed that preliminary analysis showed that remdesivir did not improve mortality rate but it decreased time to recovery by as much as $30 \%$ (96). Multiple clinical trials into its efficacy are still in progress, including DisCoVeRy by INSERM (NCT04315948), ACTT through NIAID (NCT04280705) and studies through Capital Medical University (NCT04252664; NCT04257656) and Gilead (NCT04292730; NCT04292899).

\section{Chloroquine and hydroxychloroquine}

Traditionally used as anti-malarials, both chloroquine and hydroxychloroquine increase endosomal $\mathrm{pH}$ required for viral fusion in coronavirus infection and affect construction of receptors in SARS-CoV (94). There is some evidence that both drugs had efficacy against SARSCoV and SARS-CoV-2 $(94,97,98)$. Both drugs have a long history of use and a well-established adverse effect profile; they have been suggested for use in treating COVID-19. A State Council of China news briefing in February 2020 reported that chloroquine phosphate was superior in a treatment arm as compared to controls in improving clinical outcomes (99). An expert consensus supporting its use has been released (100) but its efficacy has yet to be conclusively demonstrated in clinical trials. A non-randomised control trial in France found that hydroxychloroquine reduced nasal viral load six days post-treatment and had high efficacy when combined with azithromycin. 
medRxiv preprint doi: https://doi.org/10.1101/2020.05.14.20102475; this version posted May 20, 2020. The copyright holder for this preprint (which was not certified by peer review) is the author/funder, who has granted medRxiv a license to display the preprint in perpetuity. It is made available under a CC-BY-NC-ND 4.0 International license .

But there was no correlation with reported clinical outcomes (101). In a randomised trial of hydroxychloroquine among hospitalised patients, the drug improved clinical symptoms when compared to standard of care but did not improve negative conversion rate of SARS-CoV-2 (102). In another trial involving hospitalised patients in China (currently awaiting peer-review), the drug reduced the time to recovery from fever, cough and pneumonia (18). More recently, observational studies involving 1,376 patients with COVID-19 in the United States showed no significant association between hydroxychloroquine use for severe illness and intubation or death (103).

Multiple trials are currently underway to assess the efficacy of these drugs for COVID-19 treatment. This include THDMS-COVID19 through Rajavithi hospital (NCT04303299), Alliance Covid-19 Brasil II through the Hospital Israelita Alberta Einstein (NCT04321278), NO COVID19 through University hospital, Akershus (NCT04316377) and HCQ4COV19 through Dundacio Lluita Contra la DIDA (NCT04304053).

\section{Ritonavir/lopinavir $+/$ - interferon beta}

Ritonavir and lopinavir are protease inhibitors used in combination treatment for HIV. A study suggested that a combination therapy of the two drugs is effective against MERS in animal models (90). This combination is being trialled in COVID-19 patients (104). While an early case report showed that treatment with this therapy lead to a decrease in the viral load (105), a randomised trial of hospitalised patients with severe disease observed no benefit of the antiviral combination compared to standard of care (27).

On an ongoing basis, further studies are being conducted, including THDMS-COVID19 through Rajavithi hospital (NCT04303299), CORIPREV-LR (NCT04321174) and studies being conducted through the Asan Medical Centre (NCT04307693), first Affiliated Hospital of Zhejiang University (NCT04261907) and Tongji Hospital (NCT04255017). In addition, this combination is being trialled in patients outside of study settings (104) and is also being used as the standard of care to which new treatments are being compared.

These four medications/combinations - remdesivir, lopinavir/ritonavir, lopinavir/ritonavir + interferon beta and chloroquine - have been incorporated into the recently announced WHO megatrial (the "Solidarity Trial") - an international collaboration investigating COVID-19 treatments.

\section{Conclusion}

SARS-CoV-2, the causative agent of the novel coronavirus disease, COVID-19, has infected $\sim 4$ million people and caused $\sim 140,000$ deaths globally. A clear description of symptoms associated with the disease is crucial to define the case definition for clinical management and for epidemiological purposes. The majority of patients are likely to remain asymptomatic or mildly symptomatic. Those that do develop clinical disease will usually have fever and cough. The presence of either of these symptoms should be a basis for suspecting a SARS-CoV-2 infection. However, since other respiratory viruses present with similar symptoms, a laboratory test specific to SARS-CoV-2 should be performed. 
Nearly, every country in the world has been hit by this pandemic. It is important to note that the definitions for COVID-19 cases vary slightly between countries and territories affected by the disease and this in turn may have affected the public health response. When defining cases, it is important that national guidelines factor in the presence of co-morbidities including cardiovascular diseases, diabetes and cancer, which increase the risk of developing severe and/or critical disease and increase the risk of fatality. Where transmission is still in the exponential phase of SARSCoV-2 infections, it is critical that clinical cases are triaged to prioritize management and treatment without overwhelming the healthcare system.

Several drugs are in clinical trials but it may take months before any become available for clinical use. Hence, it is important that quarantine and isolation measures are strictly enforced to control the disease outbreak. A major challenge though to controlling SARS-CoV-2 transmission is how to identify the "silent spreaders" who are asymptomatic carriers of the infection.

\section{Limitations of the study}

During the review period, the data on COVID-19 constantly changed with increasing amounts of literature both peer-reviewed and non-peer-reviewed. COVID-19 data was dependent on country level definitions and testing rates.

\section{References}

1. Zhu N, Zhang D, Wang W, Li X, Yang B, Song J, et al. A Novel Coronavirus from Patients with Pneumonia in China, 2019. New England Journal of Medicine. 2020;382(8):727-33.

2. Chan JF-W, Yuan S, Kok K-H, To KK-W, Chu H, Yang J, et al. A familial cluster of pneumonia associated with the 2019 novel coronavirus indicating person-to-person transmission: a study of a family cluster. The Lancet. 2020;395(10223):514-23.

3. $\quad$ Chan-Yeung M, Xu RH. SARS: epidemiology. Respirology. 2003;8:S9-S14.

4. Sampathkumar P, Temesgen Z, Smith TF, Thompson RL, editors. SARS: epidemiology, clinical presentation, management, and infection control measures. Mayo Clinic Proceedings; 2003: Elsevier.

5. Lee N, Hui D, Wu A, Chan P, Cameron P, Joynt GM, et al. A major outbreak of severe acute respiratory syndrome in Hong Kong. New England Journal of Medicine. 2003;348(20):1986-94.

6. Guan WJ, Ni ZY, Hu Y, Liang WH, Ou CQ, He JX, et al. Clinical Characteristics of Coronavirus Disease 2019 in China. N Engl J Med. 2020.

7. Wang D, Hu B, Hu C, Zhu F, Liu X, Zhang J, et al. Clinical Characteristics of 138 Hospitalized Patients With 2019 Novel CoronavirusInfected Pneumonia in Wuhan, China. Jama. 2020.

8. Liu K, Fang YY, Deng Y, Liu W, Wang MF, Ma JP, et al. Clinical characteristics of novel coronavirus cases in tertiary hospitals in Hubei Province. Chin Med J (Engl). 2020.

9. $\quad$ Pan L, Mu, M., Yang, P., Sun, Y., Wang, R., Yan, J., Li, P., Hu, B., Wang, J., Hu, C., Jin, Y., Niu, X., Ping, R., Du, Y., Li, T., Xu, G., $\mathrm{Hu}, \mathrm{Q} ., \mathrm{Tu}, \mathrm{L}$. Clinical characteristics of COVID-19 patients with digestive symptoms in Hubei, China: a descriptive, cross-sectional, multi-center study. The American Journal of Gastroenterology. 2020;pre-print.

10. Chen N, Zhou M, Dong X, Qu J, Gong F, Han Y, et al. Epidemiological and clinical characteristics of 99 cases of 2019 novel coronavirus pneumonia in Wuhan, China: a descriptive study. Lancet. 2020;395(10223):507-13.

11. Kluytmans-van de Bergh MFQ, Buiting, A.G.M, Pas, S.D., Bentvelsen, R.G., van den Bijllaardt, W., van Oudheudsen, A., van Rijen, M.M.L., Verweij, J.J., Koopmans, M.P.G., Kluytmans, J.A.J.W. SARS-CoV infection in 86 healthcare workers in two Dutch hospitals in March 2020: a cross-sectional study with short-term follow-up. 2020.

12. Xu XW, Wu XX, Jiang XG, Xu KJ, Ying LJ, Ma CL, et al. Clinical findings in a group of patients infected with the 2019 novel coronavirus (SARS-Cov-2) outside of Wuhan, China: retrospective case series. BMJ. 2020;368:m606.

13. Yang X, Yu Y, Xu J, Shu H, Xia J, Liu H, et al. Clinical course and outcomes of critically ill patients with SARS-CoV-2 pneumonia in Wuhan, China: a single-centered, retrospective, observational study. Lancet Respir Med. 2020.

14. Song F, Shi N, Shan F, Zhang Z, Shen J, Lu H, et al. Emerging 2019 Novel Coronavirus (2019-nCoV) Pneumonia. Radiology. 2020;295(1):210-7.

15. Huang C, Wang Y, Li X, Ren L, Zhao J, Hu Y, et al. Clinical features of patients infected with 2019 novel coronavirus in Wuhan, China. Lancet. 2020;395(10223):497-506.

16. Liu M, He P, Liu HG, Wang XJ, Li FJ, Chen S, et al. [Clinical characteristics of 30 medical workers infected with new coronavirus pneumonia]. Zhonghua Jie He He Hu Xi Za Zhi. 2020;43(3):209-14. 
17. Zhao D, Yao F, Wang L, Zheng L, Gao Y, Ye J, et al. A comparative study on the clinical features of COVID-19 pneumonia to other pneumonias. Clin Infect Dis. 2020.

18. Qiu HW, J. Hong, L. Luo, Y. Song, Q. Chen, D. Clinical and epidemiological features of 36 children with coronavirus disease 2019 (COVID-19) in Zhejiang, China: an observational cohort study. The Lancet Infectious Diseases. 2020.

19. Cai J, Xu J, Lin D, Yang Z, Xu L, Qu Z, et al. A Case Series of children with 2019 novel coronavirus infection: clinical and epidemiological features. Clin Infect Dis. 2020.

20. Chen H, Guo J, Wang C, Luo F, Yu X, Zhang W, et al. Clinical characteristics and intrauterine vertical transmission potential of COVID19 infection in nine pregnant women: a retrospective review of medical records. Lancet. 2020;395(10226):809-15.

21. Worldometer. COVID-19 CORONAVIRUS PANDEMIC 2020 [Available from: https://www.worldometers.info/coronavirus/.

22. Guo ZD, Wang ZY, Zhang SF, Li X, Li L, Li C, et al. Aerosol and Surface Distribution of Severe Acute Respiratory Syndrome Coronavirus 2 in Hospital Wards, Wuhan, China, 2020. Emerg Infect Dis. 2020;26(7).

23. Modes of transmission of virus causing COVID-19: implications for IPC precaution recommendations [press release]. World Health Organisation, 29 March 20202020.

24. van Doremalen N, Bushmaker T, Morris DH, Holbrook MG, Gamble A, Williamson BN, et al. Aerosol and Surface Stability of SARSCoV-2 as Compared with SARS-CoV-1. N Engl J Med. 2020.

25. Zhang W, Du RH, Li B, Zheng XS, Yang XL, Hu B, et al. Molecular and serological investigation of 2019-nCoV infected patients: implication of multiple shedding routes. Emerg Microbes Infect. 2020;9(1):386-9.

26. To KK, Tsang OT, Chik-Yan Yip C, Chan KH, Wu TC, Chan JMC, et al. Consistent detection of 2019 novel coronavirus in saliva. Clin Infect Dis. 2020 .

27. Cao B, Wang Y, Wen D, Liu W, Wang J, Fan G, et al. A Trial of Lopinavir-Ritonavir in Adults Hospitalized with Severe Covid-19. N Engl J Med. 2020.

28. Ferner RE, Murray, P.I., Aronson, J.K. Spreading SARS-CoV-2 through ocular fluids. Centre for Evidence Based Medicine. 2020.

29. Sun T, Guan J. Novel coronavirus and central nervous system. Eur J Neurol. 2020.

30. Salata C, Calistri A, Parolin C, Palu G. Coronaviruses: a paradigm of new emerging zoonotic diseases. Pathog Dis. 2020.

31. Kucharski AJ, Russell TW, Diamond C, Liu Y, Edmunds J, Funk S, et al. Early dynamics of transmission and control of COVID-19: a mathematical modelling study. Lancet Infect Dis. 2020.

32. Frieden TR, Lee CT. Identifying and Interrupting Superspreading Events-Implications for Control of Severe Acute Respiratory Syndrome Coronavirus 2. Emerg Infect Dis. 2020;26(6).

33. Arons MM, Hatfield KM, Reddy SC, Kimball A, James A, Jacobs JR, et al. Presymptomatic SARS-CoV-2 Infections and Transmission in a Skilled Nursing Facility. N Engl J Med. 2020.

34. Backer JA, Klinkenberg D, Wallinga J. Incubation period of 2019 novel coronavirus (2019-nCoV) infections among travellers from Wuhan, China, 20-28 January 2020. Euro Surveill. 2020;25(5).

35. Jiang X, Rayner S, Luo MH. Does SARS-CoV-2 has a longer incubation period than SARS and MERS? J Med Virol. 2020.

36. Qiu H, Wu J, Hong L, Luo Y, Song Q, Chen D. Clinical and epidemiological features of 36 children with coronavirus disease 2019 (COVID-19) in Zhejiang, China: an observational cohort study. The Lancet Infectious Diseases.

37. Wang D, Hu B, Hu C, Zhu F, Liu X, Zhang J, et al. Clinical Characteristics of 138 Hospitalized Patients With 2019 Novel CoronavirusInfected Pneumonia in Wuhan, China. JAMA. 2020;323(11):1061-9.

38. Chen N, Zhou M, Dong X, Qu J, Gong F, Han Y, et al. Epidemiological and clinical characteristics of 99 cases of 2019 novel coronavirus pneumonia in Wuhan, China: a descriptive study. The Lancet. 2020;395(10223):507-13.

39. Dai W-c, Zhang H-w, Yu J, Xu H-j, Chen H, Luo S-p, et al. CT Imaging and Differential Diagnosis of COVID-19. Canadian Association of Radiologists Journal. 2020;71(2):195-200.

40. Lauer SA, Grantz KH, Bi Q, Jones FK, Zheng Q, Meredith HR, et al. The Incubation Period of Coronavirus Disease 2019 (COVID-19) From Publicly Reported Confirmed Cases: Estimation and Application. Ann Intern Med. 2020.

41. Ryu S, Chun BC, Korean Society of Epidemiology -nCo VTFT. An interim review of the epidemiological characteristics of 2019 novel coronavirus. Epidemiol Health. 2020;42:e2020006.

42. Pan F, Ye T, Sun P, Gui S, Liang B, Li L, et al. Time Course of Lung Changes On Chest CT During Recovery From 2019 Novel Coronavirus (COVID-19) Pneumonia. Radiology. 2020:200370.

43. WHO Director-General's opening remarks at the media briefing on COVID-19 - 24 February 2020 [press release]. World Health Organisation, 24 February 20202020.

44. Zhou F, Yu T, Du R, Fan G, Liu Y, Liu Z, et al. Clinical course and risk factors for mortality of adult inpatients with COVID-19 in Wuhan, China: a retrospective cohort study. The Lancet. 2020;395(10229):1054-62.

45. Linton NM, Kobayashi T, Yang Y, Hayashi K, Akhmetzhanov AR, Jung SM, et al. Incubation Period and Other Epidemiological Characteristics of 2019 Novel Coronavirus Infections with Right Truncation: A Statistical Analysis of Publicly Available Case Data. J Clin Med. $2020 ; 9(2)$.

46. WHO. Q\&A: Similarities and differences - COVID-19 and influenza 2020 [Available from: https://www.who.int/news-room/q-adetail/q-a-similarities-and-differences-covid-19-and-influenza.

47. Wang Y, Liu Y, Liu L, Wang X, Luo N, Ling L. Clinical outcome of 55 asymptomatic cases at the time of hospital admission infected with SARS-Coronavirus-2 in Shenzhen, China. J Infect Dis. 2020.

48. Dong Y, Mo X, Hu Y, Qi X, Jiang F, Jiang Z, et al. Epidemiology of COVID-19 Among Children in China. Pediatrics. 2020.

49. Gudbjartsson DF, Helgason A, Jonsson H, Magnusson OT, Melsted P, Norddahl GL, et al. Spread of SARS-CoV-2 in the Icelandic Population. N Engl J Med. 2020.

50. Mizumoto K, Kagaya K, Zarebski A, Chowell G. Estimating the asymptomatic proportion of coronavirus disease 2019 (COVID-19) cases on board the Diamond Princess cruise ship, Yokohama, Japan, 2020. Euro Surveill. 2020;25(10).

51. Stewart P, Ali I. Coronavirus clue? Most cases aboard U.S. aircraft carrier are symptom-free. Reuters. 2020 April 17, 2020.

52. Rothe C, Schunk M, Sothmann P, Bretzel G, Froeschl G, Wallrauch C, et al. Transmission of 2019-nCoV Infection from an Asymptomatic Contact in Germany. N Engl J Med. 2020;382(10):970-1.

53. Du Z, Xu X, Wu Y, Wang L, Cowling BJ, Meyers LA. Serial Interval of COVID-19 among Publicly Reported Confirmed Cases. Emerg Infect Dis. 2020;26(6).

54. Li C, Ji F, Wang L, Wang L, Hao J, Dai M, et al. Asymptomatic and Human-to-Human Transmission of SARS-CoV-2 in a 2-Family Cluster, Xuzhou, China. Emerg Infect Dis. 2020;26(7). 
55. Tong ZD, Tang A, Li KF, Li P, Wang HL, Yi JP, et al. Potential Presymptomatic Transmission of SARS-CoV-2, Zhejiang Province, China, 2020. Emerg Infect Dis. 2020;26(5).

56. Wan Y, Shang J, Graham R, Baric RS, Li F. Receptor recognition by novel coronavirus from Wuhan: An analysis based on decade-long structural studies of SARS. J Virol. 2020.

57. Li R, Pei S, Chen B, Song Y, Zhang T, Yang W, et al. Substantial undocumented infection facilitates the rapid dissemination of novel coronavirus (SARS-CoV2). Science. 2020.

58. WHO. Clinical management of severe acute respiratory infection (SARI) when COVID-19 disease is suspected.; 202013 March 2020. Contract No.: WHO/2019-nCoV/Clinical/2020.4.

59. Murthy S, Gomersall CD, Fowler RA. Care for Critically Ill Patients With COVID-19. JAMA. 2020.

60. Verity R, Okell LC, Dorigatti I, Winskill P, Whittaker C, Imai N, et al. Estimates of the severity of coronavirus disease 2019: a model-

based analysis. Lancet Infect Dis. 2020.

61. Ware L. Acute respiratory distress syndrome: BMJ Best Practice; 2020 [updated April 2020. Available from: https://www.who.int/publications-detail/clinical-management-of-severe-acute-respiratory-infection-when-novel-coronavirus-(ncov)-infection-issuspected.

62. Wu A, Peng Y, Huang B, Ding X, Wang X, Niu P, et al. Genome Composition and Divergence of the Novel Coronavirus (2019-nCoV) Originating in China. Cell Host Microbe. 2020.

63. Cui Y, Tian M, Huang D, Wang X, Huang Y, Fan L, et al. A 55-Day-Old Female Infant infected with COVID 19: presenting with pneumonia, liver injury, and heart damage. J Infect Dis. 2020

64. Wu A, Peng Y, Huang B, Ding X, Wang X, Niu P, et al. Genome Composition and Divergence of the Novel Coronavirus (2019-nCoV) Originating in China. Cell Host \& Microbe. 2020.

65. Bernheim A, Mei X, Huang M, Yang Y, Fayad ZA, Zhang N, et al. Chest CT Findings in Coronavirus Disease-19 (COVID-19): Relationship to Duration of Infection. Radiology. 2020:200463.

66. Wei M, Yuan J, Liu Y, Fu T, Yu X, Zhang ZJ. Novel Coronavirus Infection in Hospitalized Infants Under 1 Year of Age in China. JAMA. 2020.

67. Grasselli G, Pesenti A, Cecconi M. Critical Care Utilization for the COVID-19 Outbreak in Lombardy, Italy: Early Experience and Forecast During an Emergency Response. JAMA. 2020.

68. Lan L, Xu D, Ye G, Xia C, Wang S, Li Y, et al. Positive RT-PCR Test Results in Patients Recovered From COVID-19. JAMA. 2020.

69. Zhou F, Yu T, Du R, Fan G, Liu Y, Liu Z, et al. Clinical course and risk factors for mortality of adult inpatients with COVID-19 in Wuhan, China: a retrospective cohort study. Lancet. 2020;395(10229):1054-62.

70. Liang W, Guan W, Chen R, Wang W, Li J, Xu K, et al. Cancer patients in SARS-CoV-2 infection: a nationwide analysis in China. Lancet Oncol. 2020;21(3):335-7.

71. Karimi-Zarchi M, Neamatzadeh H, Dastgheib SA, Abbasi H, Mirjalili SR, Behforouz A, et al. Vertical Transmission of Coronavirus Disease 19 (COVID-19) from Infected Pregnant Mothers to Neonates: A Review. Fetal Pediatr Pathol. 2020:1-5.

72. Zhu H, Wang L, Fang C, Peng S, Zhang L, Chang G, et al. Clinical analysis of 10 neonates born to mothers with 2019-nCoV pneumonia. Transl Pediatr. 2020;9(1):51-60.

73. Zeng H, Xu C, Fan J, Tang Y, Deng Q, Zhang W, et al. Antibodies in Infants Born to Mothers With COVID-19 Pneumonia. JAMA.

2020 .

74. Wu P, Hao X, Lau EHY, Wong JY, Leung KSM, Wu JT, et al. Real-time tentative assessment of the epidemiological characteristics of novel coronavirus infections in Wuhan, China, as at 22 January 2020. Euro Surveill. 2020;25(3).

75. Oke JH, C. Global COVID-19 Case Fatality Rates. Oxford COVID-19 Evidence Service [Internet]. 202031 March 2020. Available from: https://www.cebm.net/covid-19/global-covid-19-case-fatality-rates/.

76. Rajgor DD, Lee, M. H., Archuleta, S., Bagdasarian, N. The many estimates of the COVID-19 case fatality rate. The Lancet Infectious Diseases. 2020.

77. Onder G, Rezza G, Brusaferro S. Case-Fatality Rate and Characteristics of Patients Dying in Relation to COVID-19 in Italy. JAMA. 2020.

78. $\quad$ Adhikari SP, Meng S, Wu YJ, Mao YP, Ye RX, Wang QZ, et al. Epidemiology, causes, clinical manifestation and diagnosis, prevention and control of coronavirus disease (COVID-19) during the early outbreak period: a scoping review. Infect Dis Poverty. 2020;9(1):29.

79. Hoffmann M, Kleine-Weber H, Schroeder S, Krüger N, Herrler T, Erichsen S, et al. SARS-CoV-2 Cell Entry Depends on ACE2 and TMPRSS2 and Is Blocked by a Clinically Proven Protease Inhibitor. Cell. 2020;181(2):271-80.e8.

80. Stawiski EW, Diwanji D, Suryamohan K, Gupta R, Fellouse FA, Sathirapongsasuti JF, et al. Human ACE2 receptor polymorphisms predict SARS-CoV-2 susceptibility. bioRxiv. 2020:2020.04.07.024752.

81. Li W, Zhang C, Sui J, Kuhn JH, Moore MJ, Luo S, et al. Receptor and viral determinants of SARS-coronavirus adaptation to human ACE2. EMBO J. 2005;24(8):1634-43.

82. Cao Y, Li L, Feng Z, Wan S, Huang P, Sun X, et al. Comparative genetic analysis of the novel coronavirus (2019-nCoV/SARS-CoV2) receptor ACE2 in different populations. Cell Discovery. 2020;6(1):11.

83. Cai G. Tabacco-Use Disparity in Gene Expression of ACE2, the Receptor of 2019-nCoV. Preprints. 2020

84. Zhao Y, Zhao Z, Wang Y, Zhou Y, Ma Y, Zuo W. Single-cell RNA expression profiling of ACE2, the receptor of SARS-CoV-2. bioRxiv. 2020:2020.01.26.919985.

85. Kim AY, Gandhi RT. Coronavirus disease 2019 (COVID-19): Management in hospitalized adults 2020 [updated 23 April 2020. Available from: https://www.uptodate.com/contents/coronavirus-disease-2019-covid-19-management-in-hospitalizedadults?topicRef $=126981 \&$ source $=$ see link.

86. Levitan R. This is what I learned during 10 days of treating Covid pneumonia at Bellevue Hospital. New York Times. 2020 April 20 2020; Sect. Opinion.

87. COVID-19 patients often infected with other respiratory viruses, preliminary study reports [press release]. Stanford Medicine News Centre, 29 March 20202020.

88. Grein J, Ohmagari N, Shin D, Diaz G, Asperges E, Castagna A, et al. Compassionate Use of Remdesivir for Patients with Severe Covid19. N Engl J Med. 2020.

89. Agostini ML, Andres EL, Sims AC, Graham RL, Sheahan TP, Lu X, et al. Coronavirus Susceptibility to the Antiviral Remdesivir (GS5734) Is Mediated by the Viral Polymerase and the Proofreading Exoribonuclease. mBio. 2018;9(2). 
90. Sheahan TP, Sims AC, Leist SR, Schafer A, Won J, Brown AJ, et al. Comparative therapeutic efficacy of remdesivir and combination lopinavir, ritonavir, and interferon beta against MERS-CoV. Nat Commun. 2020;11(1):222.

91. Sheahan TP, Sims AC, Graham RL, Menachery VD, Gralinski LE, Case JB, et al. Broad-spectrum antiviral GS-5734 inhibits both epidemic and zoonotic coronaviruses. Sci Transl Med. 2017;9(396).

92. de Wit E, Feldmann F, Cronin J, Jordan R, Okumura A, Thomas T, et al. Prophylactic and therapeutic remdesivir (GS-5734) treatment in the rhesus macaque model of MERS-CoV infection. Proc Natl Acad Sci U S A. 2020.

93. Gilead. Gilead's Investigational Antiviral Remdesivir Receives U.S. Food and Drug Administration Emergency Use Authorization for the Treatment of COVID-19: Gilead; 2020 [Available from: https://www.gilead.com/news-and-press/press-room/press-releases/2020/5/gileadsinvestigational-antiviral-remdesivir-receives-us-food-and-drug-administration-emergency-use-authorization-for-the-treatment-of-covid19.

94. Wang M, Cao R, Zhang L, Yang X, Liu J, Xu M, et al. Remdesivir and chloroquine effectively inhibit the recently emerged novel coronavirus (2019-nCoV) in vitro. Cell Res. 2020;30(3):269-71.

95. Holshue ML, DeBolt C, Lindquist S, Lofy KH, Wiesman J, Bruce H, et al. First Case of 2019 Novel Coronavirus in the United States. N Engl J Med. 2020;382(10):929-36.

96. BBC. Remdesivir: Drug has 'clear cut' power to fight coronavirus 2020 [Available from: https://www.bbc.com/news/health-52478783.

97. Colson P, Rolain JM, Lagier JC, Brouqui P, Raoult D. Chloroquine and hydroxychloroquine as available weapons to fight COVID-19. Int J Antimicrob Agents. 2020:105932.

98. Yao X, Ye F, Zhang M, Cui C, Huang B, Niu P, et al. In Vitro Antiviral Activity and Projection of Optimized Dosing Design of Hydroxychloroquine for the Treatment of Severe Acute Respiratory Syndrome Coronavirus 2 (SARS-CoV-2). Clin Infect Dis. 2020.

99. Gao J, Tian Z, Yang X. Breakthrough: Chloroquine phosphate has shown apparent efficacy in treatment of COVID-19 associated pneumonia in clinical studies. Biosci Trends. 2020;14(1):72-3.

100. Guangdong DoSaTo. [Expert consensus on chloroquine phosphate for the treatment of novel coronavirus pneumonia]. Zhonghua Jie He He Hu Xi Za Zhi. 2020;43(0):E019.

101. Gautret P, Lagier JC, Parola P, Hoang VT, Meddeb L, Mailhe M, et al. Hydroxychloroquine and azithromycin as a treatment of COVID19: results of an open-label non-randomized clinical trial. Int J Antimicrob Agents. 2020:105949.

102. Tang W, Cao Z, Han M, Wang Z, Chen J, Sun W, et al. Hydroxychloroquine in patients with COVID-19: an open-label, randomized, controlled trial. MedRxiv Pre-print. 2020.

103. Geleris J, Sun Y, Platt J, Zucker J, Baldwin M, Hripcsak G, et al. Observational Study of Hydroxychloroquine in Hospitalized Patients with Covid-19. New England Journal of Medicine. 2020.

104. Bhatnagar T, Murhekar MV, Soneja M, Gupta N, Giri S, Wig N, et al. Lopinavir/ritonavir combination therapy amongst symptomatic coronavirus disease 2019 patients in India: Protocol for restricted public health emergency use. Indian J Med Res. 2020.

105. Lim J, Jeon S, Shin HY, Kim MJ, Seong YM, Lee WJ, et al. Case of the Index Patient Who Caused Tertiary Transmission of COVID19 Infection in Korea: the Application of Lopinavir/Ritonavir for the Treatment of COVID-19 Infected Pneumonia Monitored by Quantitative RTPCR. J Korean Med Sci. 2020;35(6):e79.

106. WHO. Global Surveillance for human infection with coronavirus disease (COVID-19). World Health Organisation; 202020 March

2020.

107. Canada G. Interim national case definition: Coronavirus Disease (COVID-19). 2020 April 22020.

108. NSW G. COVID-19 (Coronavirus) testing advice. Health Protection NSW; 2020 March 242020.

109. Case definition and European surveillance for COVID-19, as of 2 March 2020 [press release]. European Centre for Disease Prevention and Control, 2 March 20202020.

110. COVID-19: investigation and initial clinical management of possible cases [press release]. UK Government, March 1820202020.

111. Coronavirus Disease 2019 (COVID-19) [press release]. Centers for Disease Control and Prevention, March 2420202020.

112. NHC C. Diagnosis and Treatment Protocol for Novel Coronavirus Pneumonia. National Health Commission \& State Administration of Traditional Chinese Medicine; 2020 March 32020.

113. Bham A, Bhiman J, Bongwen F, Blumberg L, Cohen C, Erasmus L, et al. Coronavirus disease 2019 (COVID-19) caused by a Novel Coronavirus (SARS-CoV-2): Guidelines for case-finding, diagnosis, management and public health response in South Africa. 2020 March 82020. Contract No.: Guidelines for COVID-19 V2.0 8-03-2020.

114. Chen T, Wu D, Chen H, Yan W, Yang D, Chen G, et al. Clinical characteristics of 113 deceased patients with coronavirus disease 2019: retrospective study. BMJ. 2020;368:m1091.

115. Remdesivir Clinical Trials: Gilead Sciences, Inc. ; 2020 [Available from: https://www.gilead.com/purpose/advancing-globalhealth/covid-19/remdesivir-clinical-trials.

116. Gordon CJ, Tchesnokov EP, Feng JY, Porter DP, Gotte M. The antiviral compound remdesivir potently inhibits RNA-dependent RNA polymerase from Middle East respiratory syndrome coronavirus. J Biol Chem. 2020;295(15):4773-9.

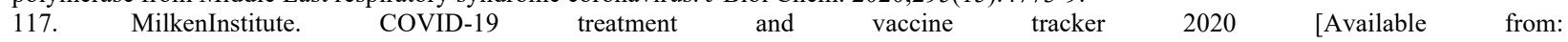
https://docs.google.com/document/d/1Y4nCJJ4njzD1wiHbufCY6gqfRmj49Qn qNgOJD62Wik/edit\#heading=h.tbce5nbt6cp9.

118. Roivant announces development of anti-GM-CSF monoclonal antibody to prevent and treat acute respiratory distress syndrome (ARDS) in patients with COVID-19: Roivant Sciences; 2020 [cited 2020 28/04/2020]. Available from: https://roivant.com/roivant-announces-developmentof-anti-gm-csf-monoclonal-antibody-to-prevent-and-treat-acute-respiratory-distress-syndrome-ards-in-patients-with-covid-19/.

119. Vijayvargiya P, Garrigos ZE, Almeida M, Gurram PR, Stevens RW, Razonable M, et al. Treatment Considerations for COVID-19: A Critical Review of the Evidence (or Lack Thereof). Mayo Clin Proc. 2020;95.

120. Acute Respiratory Distress Syndrome (ARDS): Athersys Inc. ; 2020 [Available from: https://www.athersys.com/clinicaltrials/ards/default.aspx.

121. Khoury M, Cuenca J, Cruz FF, Figueroa FE, Rocco PR, Weiss DJ. Current Status of Cell-Based Therapies for Respiratory Virus Infections: Applicability to COVID-19. European Respiratory Journal. 2020.

122. Lee RH, Pulin AA, Seo MJ, Kota DJ, Ylostalo J, Larson BL, et al. Intravenous hMSCs improve myocardial infarction in mice because cells embolized in lung are activated to secrete the anti-inflammatory protein TSG-6. Cell Stem Cell. 2009;5(1):54-63.

123. Krasnodembskaya A, Song Y, Fang X, Gupta N, Serikov V, Lee J-W, et al. Antibacterial effect of human mesenchymal stem cells is mediated in part from secretion of the antimicrobial peptide LL-37. Stem Cells. 2010;28(12):2229-38.

124. Hu S, Park J, Liu A, Lee J, Zhang X, Hao Q, et al. Mesenchymal Stem Cell Microvesicles Restore Protein Permeability Across Primary Cultures of Injured Human Lung Microvascular Endothelial Cells. Stem Cells Transl Med. 2018;7(8):615-24. 
125. Evaluation of Ganovo (Danoprevir) combined with Ritonavir in the treatment of SARS-CoV-2 infection NIH U.S. National Library of Medicine2020 [cited 2020 28/04/2020]. Available from: https://clinicaltrials.gov/ct2/show/NCT04291729.

126. Chen H, Zhang Z, Wang L, Huang Z, Gong F, Li X, et al. First Clinical Study Using HCV Protease Inhibitor Danoprevir to Treat Naive and Experienced COVID-19 Patients. medRxiv. 2020:2020.03.22.20034041.

127. Sorrento to provide manufacturing support to Celularity as CYNK-001 NK cell trial for COVID-19 begins enrolling patients $\begin{array}{llllll}\text { GlobeNewswire2020 } & \text { [cited } 2020 \quad \text { 28/04/2020]. Available from: http://www.globenewswire.com/news- }\end{array}$ release/2020/04/02/2010998/0/en/SORRENTO-TO-PROVIDE-MANUFACTURING-SUPPORT-TO-CELULARITY-AS-CYNK-001-NKCELL-TRIAL-FOR-COVID-19-BEGINS-ENROLLING-PATIENTS.html.

128. Luevano M, Madrigal A, Saudemont A. Generation of natural killer cells from hematopoietic stem cells in vitro for immunotherapy. Cellular \& molecular immunology. 2012;9(4):310-20.

129. I-Mab to develop therapy for Covid-19-related cytokine storm: Pharmaceutical Technology; 2020 [cited 2020 28/04/2020]. Available from: https://www.pharmaceutical-technology.com/news/i-mab-covid-19-cytokine-storm-therapy/.

130. Ridgeback Biotherapeutics and DRIVE to develop Covid-19 drug: Pharmaceutical Technology; 2020 [cited 2020 28/04/2020]. Available from: https://www.pharmaceutical-technology.com/news/ridgeback-biotherapeutics-covid-19/.

131. CSL Behring and SAB Biotherapeutics join forces to deliver new potential COVID-19 therapeutic CSL; 2020 [cited 2020 28/04/2020]. Available from: https://www.csl.com/news/2020/sab-covid-19.

132. AlloVir expands its research collaboration with Baylor College of Medicine to discover and develop allogeneic, off-the-shelf, virusspecific T-cell therapies for COVID-19: AlloVir 2020 [cited 2020 28/04/2020]. Available from: https://www.allovir.com/news-blog/allovirexpands-its-research-collaboration-with-baylor-college-of-medicine-to-discover-and-develop-allogeneic-off-the-shelf-virus-specific-t-celltherapies-for-covid-19.

133. Cross R. Amgen and Adaptive pursue COVID-19 antibody therapy: Chemical and Engineering News; 2020 [cited 2020 28/04/2020]. Available from: https://cen.acs.org/pharmaceuticals/biologics/Amgen-Adaptive-pursue-COVID-19/98/i14.

134. Piro A, Tagarelli A, Tagarelli G, Lagonia P, Quattrone A. Paul Ehrlich: The Nobel Prize in Physiology or Medicine 1908. International Reviews of Immunology. 2008;27(1-2):1-17.

135. Snyder B. Vanderbilt University Medical Center and AstraZeneca join forces to identify potential COVID-19 treatments: Vnderbilt University Medical Center; 2020 [cited 2020 28/04/2020]. Available from: https://news.vumc.org/2020/04/08/vanderbilt-university-medicalcenter-and-astrazeneca-join-forces-to-identify-potential-covid-19-treatments/.

136. Celltrion identifies antibody candidates against COVID-19: Pharmaceutical Technology; 2020 [cited 2020 28/04/2020]. Available from: https://www.pharmaceutical-technology.com/news/celltrion-identifies-covid-19-antibodies/.

137. Lilly Begins Clinical Testing of Therapies for COVID-19: Lilly; 2020 [cited 2020 28/04/2020]. Available from: https://investor.lilly.com/news-releases/news-release-details/lilly-begins-clinical-testing-therapies-covid-19.

138. Li G, He X, Zhang L, Ran Q, Wang J, Xiong A, et al. Assessing ACE2 expression patterns in lung tissues in the pathogenesis of COVID19. Journal of autoimmunity. 2020:102463-.

139. Grifols Announces Formal Collaboration with US Government to Produce the First Treatment Specifically Targeting COVID-19: Grifols; 2020 [cited 2020 28/04/2020]. Available from: https://www.grifols.com/en/view-news/-/news/grifols-announces-formal-collaborationwith-us-government-to-produce-the-first-treatment-specifically-targeting-covid-19.

140. Neurimmune and Ethris Sign Collaboration Agreement to Rapidly Develop Inhaled mRNA-based Antibody Therapy for the Treatment of Covid-19: Neurimmune; 2020 [cited 2020 28/04/2020]. Available from: https://www.neurimmune.com/news/neurimmune-and-ethris-signcollaboration-agreement-to-rapidly-develop-inhaled-mrna-based-antibody-therapy-for-the-treatment-of-covid-19.

141. Pfizer advances battle against COVID-19 on multiple fronts Pfizer; 2020 [cited 2020 28/04/2020]. Available from: https://www.pfizer.com/news/press-release/press-release-detail/pfizer advances battle against covid 19 on multiple fronts.

142. Regeneron's COVID-19 response efforts 2020 [cited 2020 28/04/2020]. Available from: https://www.regeneron.com/covid19.

143. COVID-19: Working Together to Go Faster for Patients: Takeda; 2020 [cited 2020 28/04/2020]. Available from: https://www.takeda.com/newsroom/featured-topics/working-together-to-go-faster-for-patients/.

144. Idrus AA. GSK becomes Vir's newest partner on COVID-19 treatments, vaccines: FierceBiotech; 2020 [cited 2020 28/04/2020]. Available from: https://www.fiercebiotech.com/biotech/gsk-becomes-vir-s-newest-partner-covid-19-treatments-vaccines.

\section{Conflict of Interest} time employment at ZiP.

804 CAN conceived and designed the study. CAN and LM performed the majority of the writing. DS, RA and JSR contributed to the writing. CAN, LM, DS and FC performed the literature review and data collection. CAN and RA performed the data analysis. RA and JSR critically revised the 
medRxiv preprint doi: https://doi.org/10.1101/2020.05.14.20102475; this version posted May 20, 2020. The copyright holder for this preprint (which was not certified by peer review) is the author/funder, who has granted medRxiv a license to display the preprint in perpetuity.

It is made available under a CC-BY-NC-ND 4.0 International license .

\section{Funding}

This work was supported by the National Health and Medical Research Council (NHMRC) of Australia [APP1161076 to J.S.R.]. Burnet Institute received funding from the NHMRC Independent Research Institutes Infrastructure Support Scheme, and the Victorian State Government Operational Infrastructure Support Scheme. The funders had no role in study design, data collection and analysis, decision to publish, or preparation of the manuscript.

\section{Figures}

Figure 1: Identification and management of COVID-19 cases.

Monitoring for suspected cases of COVID-19 is crucial to halt transmission of SARS-CoV-2. Suspected cases who have had contact with an infected person (asymptomatic/symptomatic) need to be isolated and screened for SARS-CoV-2 using sensitive nucleic acid amplification tests (NAATs). It is recommended that infected individuals who are asymptomatic self-isolate and be monitored at home. Individuals who progress to develop clinical disease can be triaged into mild/moderate and severe/critical case for clinical management/treatment. However, the presence of co-morbidities and the age of the patient can be used to triage patients for hospitalization or homecare. Once recovered, patients should be monitored since they could still be infectious.

\section{Figure 2: Commonly reported clinical symptoms of COVID-19.}

The data was obtained from 15 studies involving COVID-19 patients including children and adults. For the pooled analysis, the mean percentage of patients who developed a particular symptom was plotted with the upper standard error. Fever and cough were the commonly reported symptoms. Data was obtained from (6-20). A detailed analysis of reported clinical symptoms for each of the 15 studies is provided in Figure S1.

Figure 3: Global burden and case fatality rates of COVID-19. 
medRxiv preprint doi: https://doi.org/10.1101/2020.05.14.20102475; this version posted May 20, 2020. The copyright holder for this preprint (which was not certified by peer review) is the author/funder, who has granted medRxiv a license to display the preprint in perpetuity.

It is made available under a CC-BY-NC-ND 4.0 International license.

846 A: Total number of cases reported as of $8^{\text {th }}$ May 2020. B: Total number of deaths (primary axis) 847 and estimated case fatality rates (secondary axis) for countries with $\geq 15$ deaths reported as of $8^{\text {th }}$ 848 May 2020. Total number cases and deaths data were obtained from Worldometer 849 (https://www.worldometers.info/coronavirus/) on $8^{\text {th }}$ May 2020. OC, Oceania, SA, South 850 America, NA, North America.

Figure S1: Commonly reported COVID-19 clinical symptoms in 15 studies.

854 For each study, the percentage of patients who developed a particular symptom was plotted. Fever 


\section{Tables}

866 Table 1: Case definitions of COVID-19

\begin{tabular}{|c|c|c|c|c|c|}
\hline Case definitions & Confirmed case & Suspect case & Probable case & Contact & Other relevant defined terms \\
\hline $\begin{array}{l}\text { WHO } \\
\text { (106) }\end{array}$ & $\begin{array}{lr}\text { A person with } \\
\text { laboratory } \\
\text { confirmation of SARS- } \\
\mathrm{CoV}-2 \text { infection } \\
\text { regardless } \\
\text { signs/symptoms }\end{array}$ & $\begin{array}{l}\text { a. Acute respiratory illness (fever \& } \\
\geq 1 \text { sign/symptom of respiratory } \\
\text { disease) and travel to a region } \\
\text { reporting community transmission } \\
\text { in } 14 \text { days prior to symptom onset } \\
\text { OR } \\
\text { b. Acute respiratory illness AND } \\
\text { contact with confirmed or probable } \\
\text { case in } 14 \text { days prior to symptom } \\
\text { onset } \\
\text { OR } \\
\text { c. Severe acute respiratory illness } \\
\text { (requiring hospitalisation) AND the } \\
\text { absence of an alternative diagnosis } \\
\text { to fully explain the presentation }\end{array}$ & $\begin{array}{l}\text { a. A suspect case in whom } \\
\text { testing is inconclusive } \\
\text { OR } \\
\text { b. A suspect case for whom } \\
\text { testing could not be performed }\end{array}$ & $\begin{array}{l}\text { Experienced any one of the following: } \\
\text { a. Face-to-face contact with a probable or } \\
\text { confirmed case within } 1 \text { meter and for more than } \\
15 \\
\text { OR minutes; } \\
\text { b. Direct physical contact with a probable or } \\
\text { confirmed } \\
\text { OR c. Direct care for a patient with probable or } \\
\text { confirmed COVID-19 disease without using } \\
\text { proper personal protective equipment; } \\
\text { OR d. Other situations as indicated by local risk } \\
\text { assessments. } \\
\text { Note: for confirmed asymptomatic cases, the } \\
\text { period of contact is measured as the } 2 \text { days before } \\
\text { through the } 14 \text { days after the date on which the } \\
\text { sample was taken which led to confirmation. } \\
\text { Note: this may occur during } 2 \text { days prior to } 14 \\
\text { days after symptom onset in a } \\
\text { suspected/confirmed case }\end{array}$ & \\
\hline $\begin{array}{l}\text { Canada } \\
\text { (107) }\end{array}$ & $\begin{array}{l}\text { Patient with laboratory } \\
\text { confirmed SARS- } \\
\text { CoV-2 infection with: } \\
\text { a. Test performed at a } \\
\text { reference laboratory } \\
\text { AND b. Consists of } \\
\text { NAAT on at least two } \\
\text { specific genome } \\
\text { targets or a single } \\
\text { positive target with } \\
\text { nucleic acid } \\
\text { sequencing }\end{array}$ & & $\begin{array}{l}\text { a. Fever }\left(\geq 38^{\circ} \mathrm{C}\right) \mathrm{AND} / \mathrm{OR} \text { new } \\
\text { onset/exacerbation of cough } \\
\text { AND } \\
\text { b. Meets COVID-19 exposure } \\
\text { criteria } \\
\text { AND } \\
\begin{array}{l}\text { c. Laboratory diagnosis is } \\
\text { inconclusive, negative or } \\
\text { positive but not yet confirmed } \\
\text { by testing authority }\end{array}\end{array}$ & $\begin{array}{l}\text { Person who provided care for patient } \\
\text { OR Had other similar close physical contact } \\
\text { OR Lived with or otherwise had close prolonged } \\
\text { contact with probable or confirmed case while the } \\
\text { case was ill }\end{array}$ & $\begin{array}{l}\text { Exposure: } \\
\text { In } 14 \text { days before onset of illness, has: } \\
\text { a. Travelled to an affected area } \\
\text { b. Had close contact with } \\
\text { confirmed/probably case } \\
\text { c. Had close contact with a person with } \\
\text { acute respiratory illness who has been to } \\
\text { an affected area within } 14 \text { days of illness } \\
\text { onset } \\
\text { d. Had laboratory exposure to biological } \\
\text { materials containing SARS-CoV-2 }\end{array}$ \\
\hline $\begin{array}{l}\text { Australia } \\
\text { (108) }\end{array}$ & $\begin{array}{l}\text { A person who: } \\
\text { a. Tests positive to a } \\
\text { validated specific } \\
\text { SARS-CoV-2 nucleic } \\
\text { acid rid test } \\
\text { OR b. has the virus } \\
\text { identified by electron } \\
\text { microscopy or viral } \\
\text { culture } \\
\text { AND test is performed }\end{array}$ & $\begin{array}{l}\text { a. Close contact with confirmed case } \\
\text { OR international travel or cruise ship } \\
\text { crew/passenger within } 14 \text { days prior } \\
\text { and meets criteria (a) for probable } \\
\text { case OR b. High risk setting and } \\
\text { meets criteria (a) for probable case } \\
\text { OR c. HCW/residential care worker } \\
\text { and meets criteria (a) for probable } \\
\text { case. OR d. Hospitalised patients } \\
\text { with fever }\left(\geq 38^{\circ} \mathrm{C}\right) \text { AND acute }\end{array}$ & $\begin{array}{l}\text { a. Fever }\left(\geq 38^{\circ} \mathrm{C}\right) \text { OR history of } \\
\text { fever (e.g. chills, sweats) } \\
\text { OR acute respiratory infection } \\
\text { (e.g. cough, shortness of breath, } \\
\text { sore throat) } \\
\text { AND } \\
\text { b. Household contact of } \\
\begin{array}{l}\text { confirmed case of COVID-19 } \\
\text { where testing has not been } \\
\text { conducted }\end{array}\end{array}$ & $\begin{array}{l}\text { a. } \geq 15 \text { minutes face-to-face contact with a } \\
\text { confirmed case, up to } 24 \text { hours before symptom } \\
\text { onset that in } \\
\text { OR } \\
\text { b. Sharing of a closed space with a confirmed case } \\
\text { for } \geq 2 \text { hours, up to } 24 \text { hours before the symptom } \\
\text { onset in that case } \\
\text { The definition includes also direct contact of body } \\
\text { fluids/laboratory specimens, aircraft passengers } \\
\text { within } 2 \text { rows and all crew members }\end{array}$ & 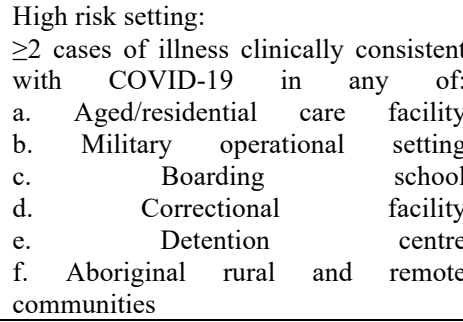 \\
\hline
\end{tabular}




\begin{tabular}{|c|c|c|c|c|c|}
\hline & $\begin{array}{ll}\text { at } \underset{\text { laboratory }}{\mathrm{a}} & \text { reference } \\
\text { labar }\end{array}$ & $\begin{array}{l}\text { respiratory symptoms (e.g. cough, } \\
\text { shortness of breath, sore throat) of } \\
\text { unknown cause }\end{array}$ & & $\begin{array}{l}\text { An extended definition of "casual contacts" is also } \\
\text { available. }\end{array}$ & $\begin{array}{l}\text { g. Settings where outbreaks have } \\
\text { occurred }\end{array}$ \\
\hline $\begin{array}{l}\text { European Centre } \\
\text { for Disease } \\
\text { Prevention and } \\
\text { Control } \\
\text { (109) }\end{array}$ & As per WHO definition & As per WHO definition & $\begin{array}{l}\text { a. Suspected case for whom } \\
\text { testing is inconclusive } \\
\text { OR F } \\
\text { b. For whom testing was } \\
\text { positive on a pan-coronavirus } \\
\text { assay }\end{array}$ & $\begin{array}{l}\text { Any } \\
\text { a. Living in the same household as a case } \\
\text { b. Having had direct physical contact with a case } \\
\text { c. Having unprotected contact with infectious } \\
\text { secretions a cas a d a d a } \\
\text { d. Having had face-to-face contact, or been in a } \\
\text { closed environment, within two metres for }>15 \\
\text { minutes } \\
\text { e. Health Care Worker or other person providing } \\
\text { direct care, or handling specimens, without } \\
\text { adequate } \\
\text { f. Within two seats on an airplane }\end{array}$ & --------- \\
\hline $\begin{array}{l}\text { UK } \\
(110)\end{array}$ & & & & & $\begin{array}{l}\text { Possible case: } \\
\text { a. Requiring admission to hospital AND } \\
\text { evidence of pneumonia OR ARDS OR } \\
\text { influenza-like illness } \\
\text { OR b. Well enough to remain in } \\
\text { community with new continuous cough } \\
\text { and/or high temperature }\end{array}$ \\
\hline $\begin{array}{l}\text { USA CDC } \\
\text { (111) }\end{array}$ & & & & $\begin{array}{l}\text { a. Being within } 6 \text { feet of a case for a prolonged } \\
\text { period } \\
\text { b. Having direct contact with infectious secretions } \\
\text { without adequate PPE }\end{array}$ & -о-о \\
\hline $\begin{array}{l}\text { China NHC } \\
\text { (112) }\end{array}$ & $\begin{array}{l}\text { Suspect cases with } \geq 1 \\
\text { of: } \\
\text { a) RT fluorescent PCR } \\
\text { positive for nCoV } \\
\text { b) Viral gene sequence } \\
\text { highly homologous for } \\
\text { nCoV } \\
\text { c) Virus-specific IgM } \\
\text { and IgG detectable in } \\
\text { serum, with IgG at } \\
\text { least 4-fold increase } \\
\text { during convalescence }\end{array}$ & 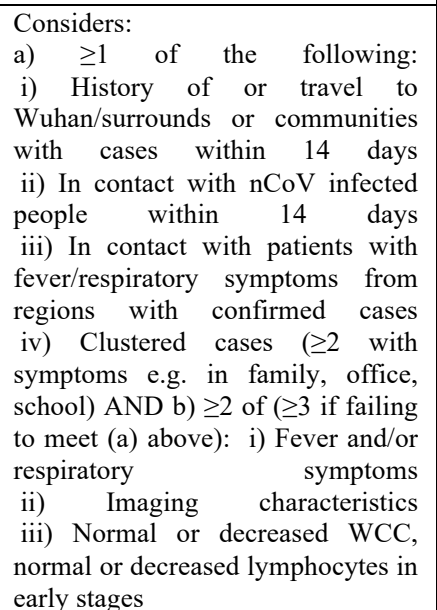 & -------- & & --------- \\
\hline $\begin{array}{l}\text { NICD, South } \\
\text { Africa (113) }\end{array}$ & $\begin{array}{l}\text { Laboratory-confirmed } \\
\text { infection with SARS- } \\
\text { CoV-2 }\end{array}$ & $\begin{array}{l}\text { Defined as PUI (person under } \\
\text { investigation) } \\
\text { a) Acute respiratory illness }(\geq 1 \text { of } \\
\text { fever, cough, sore throat, shortness } \\
\text { of } \quad \text { breath) }\end{array}$ & $\begin{array}{l}\text { Person under investigation for } \\
\text { whom SARS-CoV-2 testing is } \\
\text { inconclusive } \\
\text { OR }\end{array}$ & $\begin{array}{llr}\text { A } & \text { person } & \text { having: } \\
\text { a) face-to-face contact }(\leq 2 \mathrm{~m}) \text { or being in a closed } \\
\text { environment with a COVID-19 } & \text { case } & \text { OR } \\
\text { b) HCW/person providing care while not wearing } \\
\text { recommended } & \text { PPE } & \text { OR }\end{array}$ & -------- \\
\hline
\end{tabular}




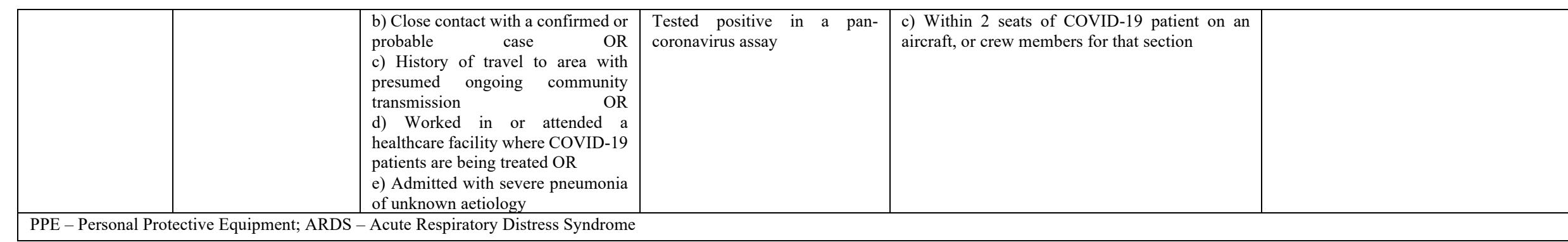

Table 2: Factors associated with severe COVID-19 and mortality

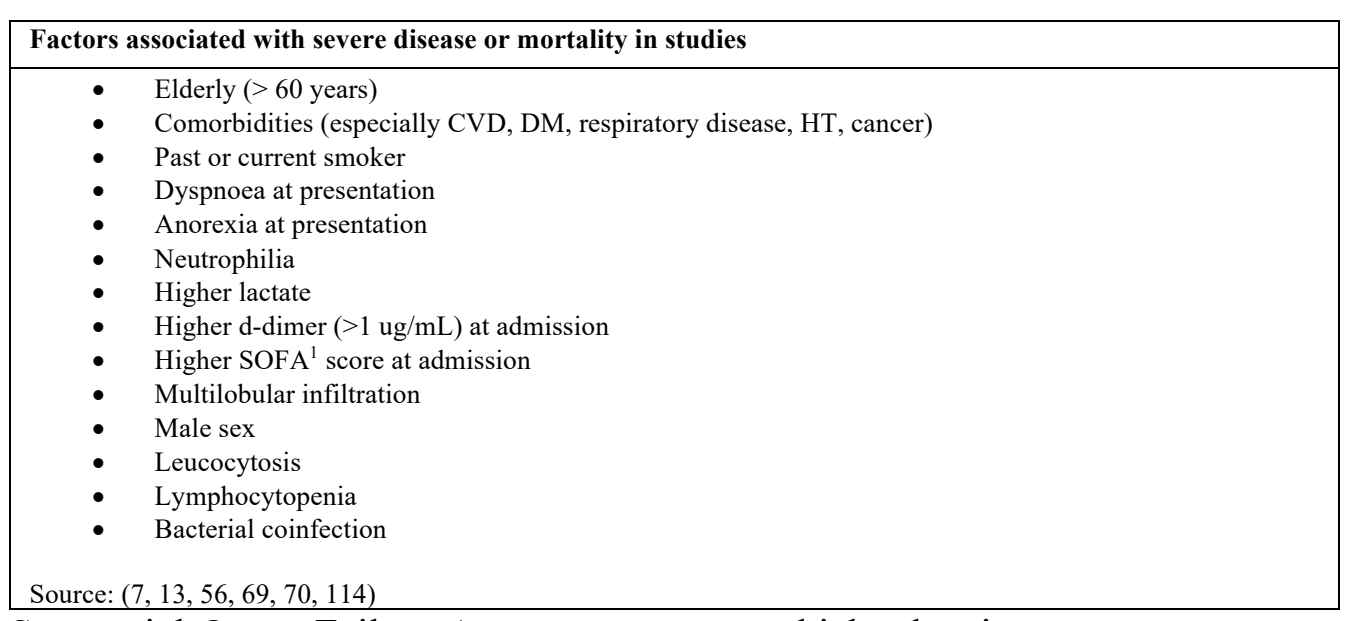

876 Sequential Organ Failure Assessment score, which takes into account measures of organ function including PaO2, FiO2, mechanical 877 ventilation, platelet count, bilirubin, GCS, MAP and creatinine 
879

880

881

882

883

884

885

886

887

888

889

890

891

892

893

894

895

896

897

898

899

900

901

902

903

904

905

906

907

908

909

910

911 
912 Table 3: Current treatments in development and in clinical trials for COVID-19

\begin{tabular}{|c|c|c|c|c|c|}
\hline Drug/treatment & Description/mode of action & Clinical trial stage & Manufacturer & Comments & Reference \\
\hline Remdesivir & $\begin{array}{l}\text { Block viral replication by acting as a } \\
\text { competitive inhibitor to RNA-dependent } \\
\text { RNA polymerase }\end{array}$ & Phase 3 & Gilead Sciences & $\begin{array}{l}\text { Broad spectrum antiviral drug tested on MERS- } \\
\text { CoV and SARS-CoV but not on SARS-CoV- } 2 \text {. } \\
\text { Preliminary analysis showed that remdesivir did } \\
\text { not improve mortality rate but it decreased time } \\
\text { to recovery by as much as } 30 \% \text {. }\end{array}$ & $\begin{array}{l}(115) \\
(96,116)\end{array}$ \\
\hline $\begin{array}{l}\text { Chloroquine/ } \\
\text { hydroxychloroquine }\end{array}$ & $\begin{array}{l}\text { chloroquine and hydroxychloroquine } \\
\text { increase endosomal } \mathrm{pH} \text { required for viral } \\
\text { fusion in coronavirus infection and affect } \\
\text { construction of receptors in SARS-CoV }\end{array}$ & $\begin{array}{l}\text { Multiple clinical } \\
\text { trials }\end{array}$ & Multiple manufacturers & $\begin{array}{l}\text { Multiple trials registered at clinicaltrials.gov. } \\
\text { Originally approved by FDA in } 1949 \text { for malaria } \\
\text { treatment. Now }\end{array}$ & $(117)$ \\
\hline lipinavir/ ritonavi & HIV-1 protease inhibitor & Clinical & Phrma & $\begin{array}{l}\text { FDA approved since } 2000 \text { to treat HIV-1 } \\
\text { infections }\end{array}$ & $(117)$ \\
\hline Gimsilumab & $\begin{array}{l}\text { Monoclonal antibody against GM-CSF } \\
\text { protein, helps reduce inflammation to treat } \\
\text { and/or prevent the onset of acute respiratory } \\
\text { distress syndrome (ARDS) }\end{array}$ & Phase 3 & Roivant Sciences & $\begin{array}{l}\text { Blocking GM-CSF inhibits downstream } \\
\text { signalling pathways, preventing the onset of } \\
\text { cytokine storm }\end{array}$ & $(118)(119)$ \\
\hline MultiStem & $\begin{array}{l}\text { Stem-cell therapy used to treat ARDS by } \\
\text { harvesting stem cell from adult bone marrow }\end{array}$ & Phase 2 & Athersys & $\begin{array}{l}\text { Stem cell therapy facilitates in clearing the virus } \\
\text { through apoptosis and phagocytosis. Steam cell } \\
\text { therapy also releases mediators such as anti- } \\
\text { inflammatory cytokines, antimicrobial peptides } \\
\text { and restore protein permeability of endothelial } \\
\text { cells. }\end{array}$ & $\begin{array}{l}(120) \\
(121) \\
(122) \\
(123) \\
(124)\end{array}$ \\
\hline $\begin{array}{ll}\text { Danoprevir } & \text { and } \\
\text { Ritonavir } & \end{array}$ & $\begin{array}{l}\text { Danoprevir is a protease inhibitor which has } \\
\text { high affinity binding to SARS-CoV-2 } \\
\text { protease, preventing the cleavage of the } \\
\text { polyprotein that forms the replicase- } \\
\text { transcriptase complex. Ritaonavir is also a } \\
\text { protease inhibitor, but serves to enhance the } \\
\text { concentration of danoprevir. }\end{array}$ & Phase 1 & Ascletis Pharma & $\begin{array}{l}\text { Antiviral combination therapy, danoprevir used } \\
\text { to treat Hepatitis C and Ritonavir used to treat } \\
\text { Human immunodeficiency virus (HIV). } \\
\text { Protease function in both Hepatitis C and HIV is } \\
\text { similar to SARS-CoV-2 protease, hypothesised } \\
\text { that these drugs will inhibit SARS-CoV-2 } \\
\text { protease function. }\end{array}$ & $\begin{array}{l}(125) \\
(126)\end{array}$ \\
\hline CYNK-001 & $\begin{array}{l}\text { Generate natural killer cells through steam } \\
\text { cells differentiation }\end{array}$ & Phase 1 & Celularity & $\begin{array}{l}\text { Natural killer cells are essential in killing virally } \\
\text { infected cell, facilitating in viral elimination }\end{array}$ & $\begin{array}{l}(127) \\
(128)\end{array}$ \\
\hline TJM2 & $\begin{array}{l}\text { Formation of antibody against GM-CSF to } \\
\text { reduce inflammation and sequential ARDS } \\
\text { onset }\end{array}$ & Phase 1 & I-Mab & & $(129)$ \\
\hline EIDD-2801 & $\begin{array}{l}\text { Block viral replication by acting as a } \\
\text { ribonucleaside analogue }\end{array}$ & Phase 1 & $\begin{array}{l}\text { Ridgeback } \\
\text { Biotherapeutics }\end{array}$ & Administered orally & $(130)$ \\
\hline \multirow[t]{3}{*}{ SAB-185 } & $\begin{array}{l}\text { Polyclonal antibodies allowing more than } \\
\text { one viral protein target }\end{array}$ & Preclinical & $\begin{array}{l}\text { SAB Biotherapeutics } \\
\text { and CSL Behring }\end{array}$ & $\begin{array}{l}\text { Treatment using humanised polyclonal } \\
\text { antibodies, without the need for serum therapy } \\
\text { from COVID-19 survivors }\end{array}$ & $(131)$ \\
\hline & $\begin{array}{l}\text { In-vitro CoV activated } \mathrm{T} \text { cells to transplant } \\
\text { into patients to facilitate in eliminating active } \\
\mathrm{CoV} \text { infection }\end{array}$ & Preclinical & Allovir & $\begin{array}{l}\text { Harvesting } \mathrm{T} \text { cells from healthy donors and } \\
\text { activating them by incubating it with harmless } \\
\text { fragments of CoV }\end{array}$ & $(132)$ \\
\hline & Antibody-based treatment & Preclinical & Amgen & $\begin{array}{l}\text { Isolate neutralising } \mathrm{CoV} \text { antibodies from } \\
\text { survivors and screen them to identify the most } \\
\text { effective ones to use for the develop potential } \\
\text { treatment }\end{array}$ & $\begin{array}{l}(133) \\
(134)\end{array}$ \\
\hline
\end{tabular}




\begin{tabular}{|c|c|c|c|c|c|}
\hline & Antibody-based treatment & Preclinical & $\begin{array}{lr}\text { AstraZeneca } & \text { and } \\
\text { Vanderbilit University } \\
\text { Medical Center }\end{array}$ & $\begin{array}{l}\text { Isolating B cells from the serum of COVID-19 } \\
\text { survivors to clone and use it for potential } \\
\text { treatments. }\end{array}$ & $\begin{array}{l}(135) \\
(134)\end{array}$ \\
\hline & Antibody-based treatment & Preclinical & Celltrion & $\begin{array}{l}\text { Consolidated a library of antibodies obtained } \\
\text { from recovered patients and determine which is } \\
\text { the most effective in neutralising SARS-CoV- } 2 \text {. }\end{array}$ & $\begin{array}{l}(136) \\
(134)\end{array}$ \\
\hline \multirow[t]{5}{*}{ LY3127804 } & $\begin{array}{l}\text { Monoclonal antibody against angiopoietin } 2 \\
\text { (Ang2), to prevent the onset of ARDS and the } \\
\text { need for medical vantilators }\end{array}$ & Preclinical & Eli Lily & Blocking Ang2 reduces lung injury & $\begin{array}{l}(137) \\
(138)\end{array}$ \\
\hline & Antibody-based treatment & Preclinical & Grifols & $\begin{array}{l}\text { Obtaining plasma sample from COVID-19 } \\
\text { survivor and using it for potential COVID-19 } \\
\text { treatment }\end{array}$ & $\begin{array}{l}(139) \\
(134)\end{array}$ \\
\hline & $\begin{array}{l}\text { Drug that generates antibodies (through } \\
\text { mRNA sequencing) with these antibodies } \\
\text { localising within the lungs }\end{array}$ & Preclinical & Neurimmune and Ethris & $\begin{array}{l}\text { Ethris working on getting anti-CoV antibodies } \\
\text { directly into the lungs of infected individuals via } \\
\text { inhaler and Neurimmune trying to identify } \\
\text { neutralising antibodies from COVID-19 } \\
\text { survivors. }\end{array}$ & $\begin{array}{l}(140) \\
(134)\end{array}$ \\
\hline & $\begin{array}{l}\text { Block viral replication by targeting viral } \\
\text { replication enzyme }\end{array}$ & Preclinical & Pfizer & $\begin{array}{l}\text { Similar compounds Pfizer used previously to } \\
\text { develop SARS-CoV antiviral medication }\end{array}$ & $(141)$ \\
\hline & Antibody-based treatment & Preclinical & $\begin{array}{l}\text { Regeneron } \\
\text { Pharmaceuticals }\end{array}$ & $\begin{array}{l}\text { Formation of SARS-CoV-2 antibodies through } \\
\text { infecting mice with harmless analogs of SARS- } \\
\text { CoV-2 }\end{array}$ & $(142)$ \\
\hline \multirow[t]{2}{*}{ CoVIg-19 } & Antibody-based treatment & Preclinical & $\begin{array}{l}\text { Takeda, CSL Behring, } \\
\text { Biotest, BPL, LFB and } \\
\text { Octapharma }\end{array}$ & $\begin{array}{l}\text { Obtaining plasma sample from COVID-19 } \\
\text { survivors and isolating protective antibodies. }\end{array}$ & $\begin{array}{l}(143) \\
(134)\end{array}$ \\
\hline & Block viral replication & Preclinical & $\begin{array}{l}\text { Vir Biotechnology and } \\
\text { GlaxoSmithKline } \\
\text { (GSK) }\end{array}$ & & $(144)$ \\
\hline
\end{tabular}





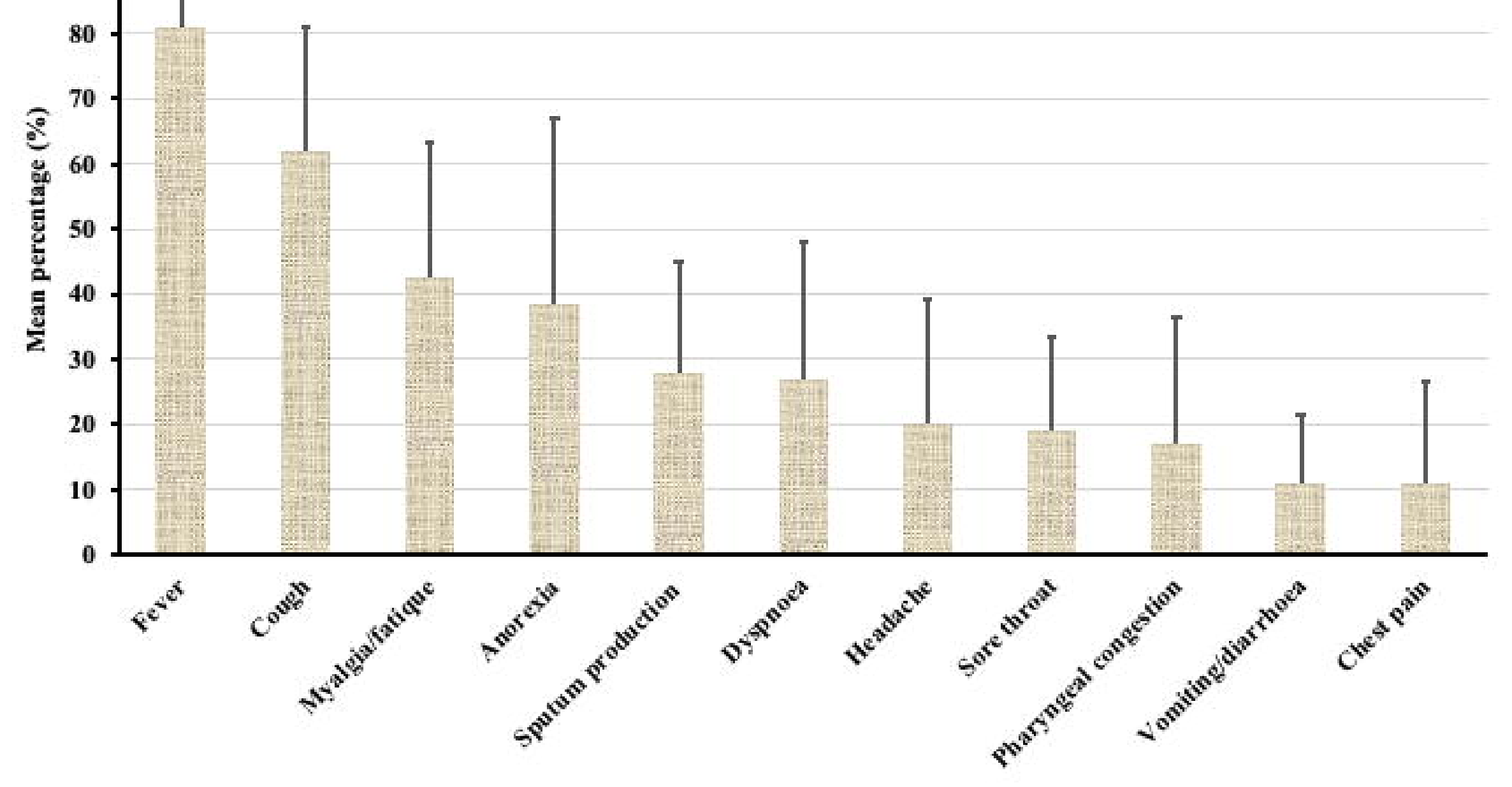





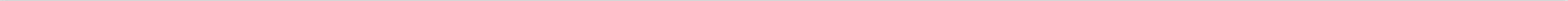

